
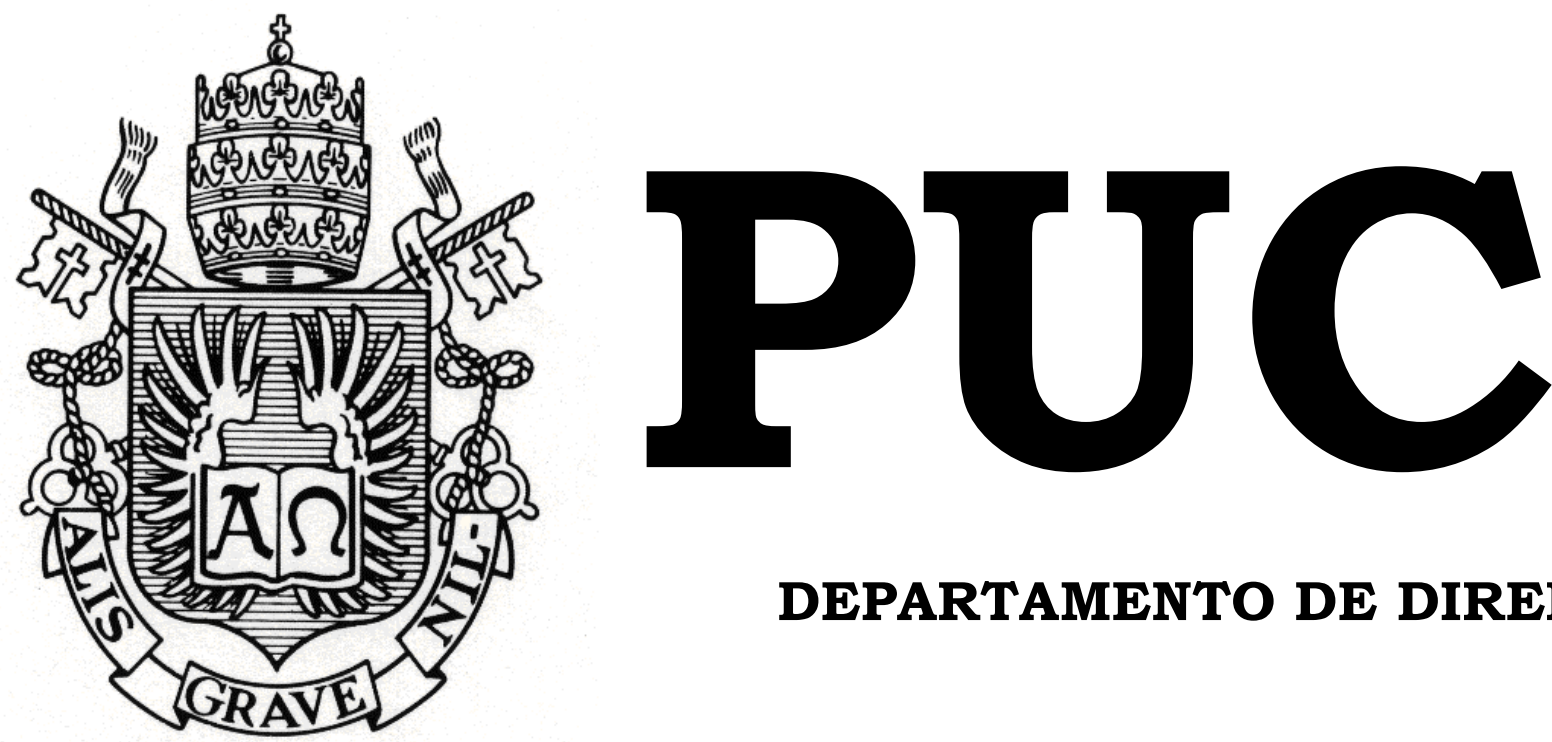

DEPARTAMENTO DE DIREITO

\title{
OFERTA PÚBLICA DE CONDO-HOTEL E A COMISSÃO DE VALORES MOBILIÁRIOS
}

por

\section{CLARA TAVARES DE OLIVEIRA}

ORIENTADORA: Norma Jonssen Parente

2017.1

PONTIFÍCIA UNIVERSIDADE CATÓLICA DO RIO DE JANEIRO

RUA MARQUÊS DE SÃO VICENTE, 225 - CEP 22453-900

RIO DE JANEIRO - BRASIL 


\section{OFERTA PÚBLICA DE CONDO-HOTEL E A COMISSÃO DE VALORES MOBILIÁRIOS}

por

\section{CLARA TAVARES DE OLIVEIRA}

Monografia apresentada ao Departamento de Direito da Pontificia Universidade Católica do Rio de Janeiro (PUC-Rio) para a obtenção do Título de Bacharel em Direito.

Orientadora: Norma Jonssen Parente 


\section{Agradecimentos}

Agradeço, em primeiro lugar e acima de tudo, aos meus pais, Márcia e Elcio, e à minha irmã, Luísa, pelo carinho e apoio dado durante toda a minha vida e, principalmente, nesses cinco anos de faculdade, por sempre estarem ao meu lado nos momentos mais difíceis e, sobretudo, acreditarem no meu potencial.

À minha orientadora, Norma Parente, por toda paciência e disponibilidade na orientação do presente trabalho.

À Comissão de Valores Mobiliários, pela melhor experiência profissional que pude vivenciar, em especial ao Paulo Ferreira, por toda contribuição na minha formação jurídica e auxílio na elaboração desta monografia.

Às minhas amigas de faculdade, Caroline Carneiro e Julia Potsch, que fizeram dos dias de estudo muito mais leves e felizes.

Ao Hugo, por tudo. 


\section{Resumo}

Com a escolha do Brasil para sediar a Copa do Mundo de 2014 e os Jogos Olimípicos de 2016, despontou-se a necessidade de construção de novos empreendimentos hoteleiros que satisfizessem e acolhessem os turistas e atletas atraídos por tais eventos esportivos. Diante dessa panorâma, viu-se a possibilidade de implantação de um novo modelo de investimento hoteleiro, os condo-hotéis, uma vez que atenderiam às necessidades do turismo brasileiro, bem como atrairiam investidores para rentabilizar o empreendimento. Tendo em vista o seu caráter de investimento financeiro, as ofertas públicas de condo-hotéis deveriam ser previamente registradas ou dispensadas de registro pela Comissão de Valores Mobiliários. Contudo, seja por desconhecimento ou má-fé, os agentes do mercado condo-hoteleiro passaram a ofertá-los irregularmente, de modo a ignorar a atuação da autarquia, a qual, verificando tais irregularidades, vem se aperfeiçoando na criação de mecanismos regulatórios cada vez mais eficientes. Nesse sentido, o presente trabalho tem como escopo o estudo do tratamento dado pela CVM às ofertas públicas de condo-hotel a fim de analisar, sobretudo, as atualizações e mudanças dessa regulação, visando o melhor funcionamento desse mercado e, principalmente, a proteção do investidor.

\section{Palavras-chave:}

Valor Mobiliário. Mercado de capitais. Condo-hotel. Contrato de Investimento Coletivo Hoteleiro. Comissão de Valores Mobiliários. Empreendimento Hoteleiro. Mercado de Capitais. Deliberação CVM nº. $734 / 2015$. 


\section{Sumário}

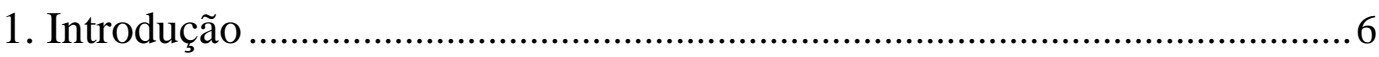

2. Origem do conceito "valor mobiliário" .........................................................

2.1. Conceito de "valor mobiliário" no direito norte-americano .................. 11

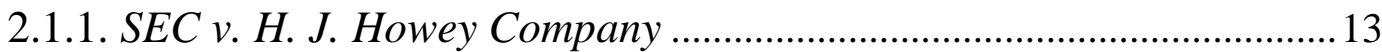

2.2. Conceito de "valor mobiliário" no direito brasileiro............................... 14

2.2.1. Perspectiva legal ....................................................................................... 16

2.2.2. Voto do ex-diretor Marcos Pinto no Processo CVM n.

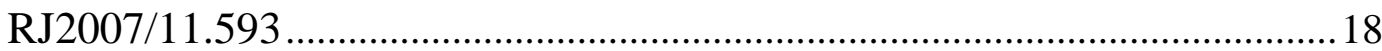

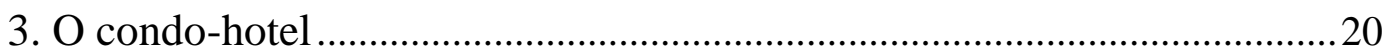

3.1. Breve histórico do investimento hoteleiro no Brasil ...............................20

3.2. Conceito de "condo-hotel" no Brasil .......................................................... 21

3.3. Agentes do mercado condo-hoteleiro ........................................................ 24

3.4. Funcionamento dos empreendimentos condo-hoteleiros .......................2 26

3.5. Condo-hotel como valor mobiliário ....................................................... 27

4. CVM e a oferta pública de distribuição de valores mobiliários.................30

4.1. Atribuições e poderes da CVM............................................................... 30

4.2. Oferta pública de distribuição valores mobiliários..................................33

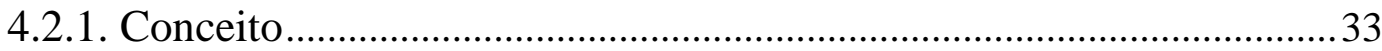

4.2.2. Registro e a Instrução CVM n ${ }^{\circ}$. 400/2003 …........................................ 36

5. Regulação da oferta-pública de condo-hotel pela CVM...........................42

5.1. Histórico das ofertas públicas de contrato de investimento coletivo

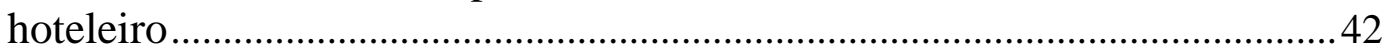

5.2. Dispensa de registro e a Deliberação CVM n ${ }^{\circ}$. 734/2015 ....................... 45

5.2.1. Direito de retratação e a Deliberação CVM n ${ }^{\circ}$. 752/2016....................48

5.3. Oferta pública irregular de contrato de investimento coletivo

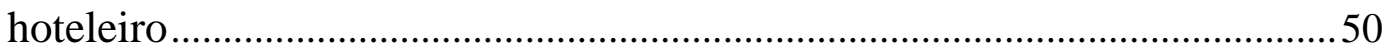

5.4. Audiência pública acerca de instrução sobre a oferta pública de

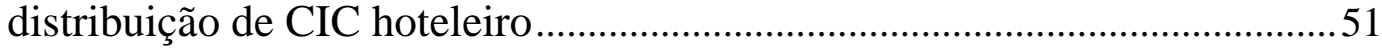

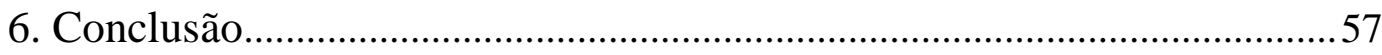

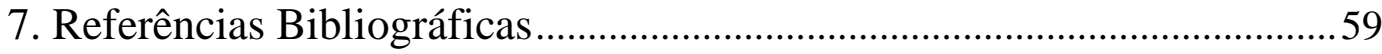




\section{Tabela de Abreviações:}

CIC - Contrato de Investimento Coletivo

CVM - Comissão de Valores Mobiliários

FOHB - Fórum de Operadores Hoteleiros no Brasil

GER-2 - Gerência de Registros 2

IPO - Inicial Public Offer

RGI - Registro Geral de Imóveis

S.A. - Sociedades Anônimas

SCP - Sociedade em Conta de Participação

SEC - Securities and Exchange Comission

SEI - Sistema Eletrônico de Informações

SRE - Superintendência de Registro de Valores Mobiliários 


\section{Introdução}

O mercado de valores mobiliários, por ser um reflexo da nossa sociedade e da sua necessidade de desenvolvimento, está em constante transição e em busca de um crescimento que possa ser equiparado aos padrões estrangeiros.

Em vista disso, a Comissão de Valores Mobiliários - CVM, criada pela Lei n. ${ }^{\circ} 6.385$ de 1976, tem como propósito velar pela eficiência e bom funcionamento do mercado de valores mobiliários brasileiro, de modo a regulá-lo através da edição de instruções normativas, deliberações, pareceres, entre outros instrumentos que estão dispostos na lei de sua criação.

Assim, para que tal regulação se concretize de forma eficaz, a CVM possui a prerrogativa de acompanhar as mudanças sociais e o seu desenvolvimento, pois, com isso, desponta o desejo de crescimento econômico dos brasileiros. Dessa maneira, é natural que surjam novos investimentos e, por conseguinte, novas espécies de valores mobiliários.

Neste contexto, de tempos em tempos, a CVM acumula à sua competência a responsabilidade de regularizar novos tipos de investimentos, e isso não foi diferente com a ascensão dos hotéiscondomínios no Brasil, cuja oferta pública passou a ser investigada e estudada pela autarquia a partir do ano de 2013.

O estudo dos hotéis-condomínio (ou condo-hotéis, como são comumente chamados) é muito importante, não só porque a sua popularidade aumenta vertiginosamente, mas também pelo fato de que a regulação de sua oferta pública vem passando por um período de diversas mudanças e atualizações.

Hoje em dia, a maioria dos hotéis de alta qualidade ou luxuosos, durante a sua fase de desenvolvimento, tem analisado a melhor alternativa de investimento hoteleiro e muitos optam por captar recursos através da modelagem de condo-hotel. 
O interesse renovado é motivado, sobretudo, pelos seguintes fatores: (i) recuperação dos mercados imobiliários residenciais, (ii) alto custo de construção de quartos de hotéis de qualidade, e (iii) a recente regulação dada pela CVM, ainda em fase de aperfeiçoamento, que modificou completamente as dinâmicas dos valores mobiliários relacionadas aos condo-hotéis.

\section{Escolha do tema}

A escolha do tema que aqui será apresentado teve origem no estágio que tive o grande prazer de vivenciar na Superintendência de Registro de Valores Mobiliários - SRE da CVM, sendo o seu início em dezembro de 2014 e término em janeiro de 2016.

No decorrer deste período, foi possível compreender mais a fundo certas questões do mercado de capitais complementares às lições dadas na faculdade, tais quais: como identificar um valor mobiliário? O que é uma oferta pública de distribuição de valores mobiliários? O que é um condohotel? Como a CVM regula as ofertas públicas de condo-hotel?

Tais indagações prenderam minha atenção e me motivaram a estudar o tema de forma mais aprofundada, uma vez que ainda é um assunto muito recente no mundo do mercado de capitais.

\section{Abordagem do tema}

Para que o trabalho em análise fosse desenvolvido, pesquisas bibliográfica e estudo de casos concretos foram utilizados. A citada pesquisa baseou-se em livros voltados para o estudo do mercado de valores mobiliários, legislações, bem como publicações da CVM e da Securiy and Exchange Comission - SEC. Já quanto ao estudo dos casos, foi desenvolvido por uma análise dos fundamentos de julgamentos sobre o tema. 
A presente monografia, a princípio, apresentará a origem do conceito de valor mobiliário, expondo como tal questão é abordada no Brasil, bem como o direito norte-americano trata e desenvolve a definição de security, uma vez que ele é a principal fonte utilizada em solo brasileiro.

Em seguida, será apresentada a definição de condo-hotel e todos os aspectos que o cercam, tais quais: o histórico do empreedimento hoteleiro no Brasil, quais são os agentes do mercado de condo-hotéis, como funciona tal mercado e as circusntâncias que levam a considerar o condo-hotel como valor mobiliário.

Posteriormente, serão analisados os poderes e atribuições da CVM, para então estudarmos a sua competência a respeito das ofertas públicas de distribuição de valores mobiliários.

Por fim, uma vez observado que condo-hotel pode ser caracterizado como um valor mobilário e, por conseguinte, a sua oferta pública deve ser regulada pela CVM, passar-se-á, portanto, a analisar o histórico do tratamento dado pela autarquia às referidas ofertas, bem como as mudanças propostas pelo órgão estatal visando o melhor funcionamento desse mercado. 


\section{Origem do conceito "valor mobiliário"}

A elaboração da definição que a seguir será apresentada, não se pode negar, é tarefa árdua devido à sua importância ao mundo do direito. Possui dois objetivos que merecem destaques, o primeiro deles é a sua função de delimitar a amplitude do direito que se origina da expressão "valor mobiliário", ao passo que o segundo é a sua prerrogativa de demarcar e balizar até que ponto a regulamentação brasileira poderá se estender a fim de regular o modo como as empresas irão promover a capitalização de recursos da poupança popular. Portanto, muito além de apenas exprimir um termo, tal conceituação se faz essencial para que os órgãos do poder executivo, que possuem a função precípua de normatizar a utilização de valores mobiliários, atuem de forma limitada.

O surgimento da expressão "valor mobiliário", em nosso país, ocorre com a criação do Banco Central do Brasil, no ano de 1964, que possuía o encargo de promover a disciplina e o desenvolvimento do mercado de capitais, como disposto na Lei $\mathrm{n}^{\mathrm{o}}$. 4.728/65. O referido diploma legal nos traz a citada expressão, contudo, o mesmo não se preocupou em conceituála, apenas fazendo remissão a "títulos ou valores mobiliários". À época, tal lacuna não representava grandes problemas, pois, naquele momento, não existia um elevado número de sociedades que ofertavam valores mobiliários.

O cenário, contudo, se transforma com o advento do ano de 1969, ano em que o mercado de valores mobiliários presenciou uma evolução nunca antes vista em solo brasileiro, fato que impulsionou a necessidade pela transformação da legislação que tratava das sociedades anônimas e, sobretudo, a criação da Comissão de Valores Mobiliários - CVM.

A Lei $n^{\circ}$. 6.385/76 criou a citada autarquia e estabeleceu, por óbvio, o seu campo de atuação. Para tal, acabou por conceituar a expressão "valor mobiliário", não cometendo o mesmo erro da Lei $n^{\circ}$. 4.728/65. Essa, contudo, não foi uma simples missão, tendo em vista a dificuldade 
enfrentada por outros ordenamentos jurídicos em prover uma definição apropriada.

Originariamente, o legislador conceituou valor mobiliário apresentando um rol exemplificativo presente no artigo $2^{\circ}$ da Lei $n^{\circ}$. 6.385/76, abaixo transcrito:

“Art. $2^{\circ}$ São valores mobiliários sujeitos ao regime desta Lei:

I - as ações, partes beneficiárias e debêntures, os cupões desses títulos e os bônus de subscrição;

II - os certificados de depósito de valores mobiliários;

III - outros títulos criados ou emitidos pelas sociedades anônimas, a critério do Conselho Monetário Nacional”.

A partir desse tipo de conceituação, podemos inferir que o legislador optou por não definir, de fato, o que é valor mobiliário, deixando a cargo do entendimento do Conselho Monetário Nacional modificar a referida lista, quando preciso.

Há duas vertentes de roupagem quanto à definição de valores mobiliários. Segundo o entendimento europeu, é mais comum que se opte por apenas definir valor mobiliário; ao passo que, segundo a jurisprudência norte-americana, é mais usual que se criem parâmetros para enquadrar certos contratos na referida categoria. Com isso, percebemos o quão importante é o papel do poder judiciário nos Estados Unidos, uma vez que o sistema da common law é fundado no estudo de precedentes e eles servirão como base para solucionar conflitos futuros, o que não ocorre no sistema europeu, que é baseado na codificação, ou seja, civil law.

O sistema seguido pelo Brasil é da civil law, ou seja, o poder judiciário brasileiro assenta suas decisões em consonância com a norma codificada, não dando muita margem para flexibilização, uma vez que se deve seguir a regra escrita. Contudo, no que diz respeito à definição de valores mobiliários, nos baseamos, em parte, no modelo norte-americano e, em vista dessa dissociação sistemática, a nossa legislação atribuiu à Comissão de Valores Mobiliários e ao Conselho Monetário Nacional a possibilidade de flexibilização dessa matéria, já que seria incompatível com 
o poder judiciário brasileiro. Melhor dizer, a Lei $n^{\circ}$. 6.385/76 elencou algumas espécies de valor mobiliário, que poderiam ser aumentadas, posteriormente, segundo o entendimento do Conselho Monetário Nacional.

A escolha desse tipo de sistemática, entretanto, pode causar certa confusão, uma vez que a solução tomada não elucida o conceito de valor mobiliário para que o mesmo seja normatizado, além de não estabelecer um critério que deverá ser seguido pelo Conselho Monetário Nacional ao criar uma nova espécie.

É de se afirmar, contudo, que a inexistência de regulação não impede a circulação de valores mobiliários, já que o funcionamento do mercado de capitais subsiste com ou sem ela; isto é, a definição de valor mobiliário é necessária somente para que se delimite o campo de atuação de órgãos governamentais na sua normatização e fiscalização, objetivando a criação de uma conjuntura equitativa do mercado.

\subsection{Conceito de "valor mobiliário" no direito norte-americano}

A princípio, se deve analisar o direito norte-americano, uma vez que ele é a principal fonte de construção da legislação brasileira sobre o tema. Nos Estados Unidos, a definição de valor mobiliário se mostrou necessária a partir de um avanço do mercado de capitais.

A legislação que iniciou $^{1}$ a regulação do referido mercado estabelecia que as companhias de investimento apenas poderiam vender obrigações, ações ou qualquer outro valor mobiliário desde que efetuado, previamente, o registro junto à autoridade competente. Com isso, percebemos que o legislador, já em 1911, deixou em aberto a possibilidade de surgimento de novas hipóteses que pudessem advir e que não fugiriam da regulação.

Com o advento da crise de 1929 surgiu a necessidade de regrar melhor esse mercado; e, com isso, o Presidente Franklin D. Roosevelt

\footnotetext{
${ }^{1}$ Lei de Kansas de 1911.
} 
aprovou o Securities Act of $1933^{2}$, que foi a primeira lei federal a regular a compra e venda de valores mobiliários. O referido diploma legal usava como alicerce para conceituar valor mobiliário as legislações de âmbito estadual, isto é, as Blue Sky Laws ${ }^{3}$. A intenção à época era que a nova lei federal pudesse atuar de forma complementar às leis estaduais, já que o 1933 Act regulamentava as vendas interestaduais de valores mobiliários que ocorriam em âmbito federal e, para tal, impunha às sociedades que objetivavam fazer a referida emissão ao público em geral o competente registro prévio perante a Federal Trade Comission ${ }^{4}$.

Assim, o conceito de valor mobiliário passou a ser definido a partir da criação de uma lista exemplificativa, em que estariam dispostas, de forma abrangente, todas as hipóteses de valor mobiliário existentes ${ }^{5}$. No entanto, prevendo que poderiam surgir novas espécies do termo em análise, o legislador deixou a cargo do poder judiciário estabelecer a caracterização de um novo gênero. No ano seguinte, contudo, o foi criado o Security and Exchange Act of $1934^{6}$ que, dentre outras finalidades, criou a Securities and

\footnotetext{
${ }^{2}$ Disponível em https://www.sec.gov/about/laws/sa33.pdf. Acesso em 29 mai. 2017.

${ }^{3}$ HAZEN, Thomas Lee, The Law of Securities Regulation. $5^{\text {a }}$ edição, Thomson/West, Hornbook Series, 2005. 20 p. O jurista esclarece a definição da expressão Blue Sky Laws: "There are numbers of explanations for the derivation of the 'blue sky' appellation, the most common of which was because of Kansas satatute's purpose to protect Kansas farmers against the industrialists selling them a price of the blue sky. A number of states fallowed suit and blue sky laws began to spring up throughout the country. Today, all states have blue sky legislation. The state blue sky laws not only focuses on providing investors with full disclosure of relevant facts, but also required them all securities registered thereunder 'qualify' on a merit basis, evaluating the substantive terms of the securities to be offered".

${ }^{4}$ Federal Trade Comission é uma agência federal americana cujas funções são a proteção dos consumidores e a promoção da concorrência entre agentes econômicos. Para mais informações, acessar: https://www.ftc.gov/. Acesso em 04 jun. 2017.

${ }^{5}$ De acordo com o Securities Act of 1933, valor mobiliário seria definido da maneira a seguir expressa: "The term 'security' means any note, stock, treasury stock, security future, securitybased swap, bond, debenture, evidence of indebtedness, certificate of interest or participation in any profit-sharing agreement, collateral-trust certificate, preorganization certificate or subscription, transferable share, investment contract, voting-trust certificate, certificate of deposit for a security, fractional undivided interest in oil, gas, or other mineral rights, any put, call, straddle, option, or privilege on any security, certificate of deposit, or group or index of securities (including any interest therein or based on the value

thereof), or any put, call, straddle, option, or privilege entered into on a national securities exchange relating to foreign currency, or, in general, any interest or instrument commonly known as a 'security', or any certificate of interest or participation in, temporary or interim certificate for, receipt for, guarantee of, or warrant or right to subscribe to or purchase, any of the foregoing".

${ }^{6}$ Disponível em https://www.sec.gov/about/laws/sea34.pdf. Acesso em 29 mai. 2017.
} 
Exchange Comission - $S E C^{7}$, bem como modificou as hipóteses de valor mobiliário mencionadas na lei federal de 1933.

Com isso, pode-se afirmar que, ao mesmo tempo em que a sua conceituação é difícil de ser apurada, a sua clareza é muito importante, para que todos entendam o seu alcance. Assim, a norma que estabelece a definição de valor mobiliário deve ser flexível para acompanhar a evolução dos investimentos do mercado de capitais, tratando os investidores com segurança.

Portanto, resta claro que nos Estados Unidos há parâmetros que auxiliam a definição de valor mobiliário presente nas citadas leis. Todavia restou à Suprema Corte o encargo de estabelecer uma conceituação mais específica à expressão em estudo, após o julgamento do leading case conhecido por SEC v. H. J. Howey Company $^{8}$, como será visto no tópico que segue.

\subsubsection{SEC v. H. J. Howey Company}

Uma das espécies elencadas como valor mobiliário no Security and Exchange Act de 1934 seriam os chamados investiment contracts que, por sua vez, não foram conceituados pelo legislador, cabendo, por conseguinte, ao poder judiciário a sua definição; como foi efetuado no leading case SEC v. H. J. Howey Company.

O referido caso é visto como uma paradigma, uma vez que tratou da controvérsia que originou a discussão sobre a designação de contrato de investimento coletivo como valor mobiliário.

A questão em análise se derivou a partir do momento em que as empresas W. J. Howey Co. e Howey-in-the-Hills Service Inc. passaram a ofertar ao público em geral, por intermédio dos correios, pequenos lotes de

\footnotetext{
${ }^{7}$ Securities and Exchange Comission é uma agência federal americana cuja função precípua é a regulação do mercado de valores mobiliários nos Estados Unidos da América. Para mais informações, acessar: https://www.sec.gov/. Acesso em 29 mai. 2017.

8 Supreme Court of the United States, 1946, 328 U.S. 293, Disponível em https://supreme.justia.com/cases/federal/us/328/293/case.html. Acesso em 29 mai. 2017.
} 
terra para que houvesse o cultivo, a colheita e a comercialização de frutas cítricas no estado da Flórida, nos Estados Unidos.

Tendo em vista que a citada oferta não possuía registro perante a Security and Exchange Comission, a mesma entrou em juízo objetivando que a negociação dos contratos de investimento coletivo ofertados cessassem, a partir de um pedido liminar de stop order; o pleito, contudo, foi negado nas duas primeiras instâncias.

O caso, então, foi parar na Suprema Corte Americana que, por sua vez, concedeu o pedido liminar, por maioria. Ela compreendeu que o contrato ofertado foi firmado com variadas pessoas que sequer conheciam, na realidade, o negócio, tornando-se, dessa forma, investidores passivos. Esse foi, portanto, o momento em que os contratos de investimento coletivo passaram a ser reconhecidos como valor mobiliário e, dessa maneira, submetidos ao estabelecido pelos Act of 1933 e Act of 1934.

Isto posto, a partir do referido caso, a Suprema Corte estabeleceu de forma estrita parâmetros para a definição de valor mobiliário, qual seja, todo contrato, transação ou esquema no qual alguém investe seu dinheiro em um empreendimento comum e espera auferir lucro, sendo este oriundo exclusivamente de esforços de terceiros ${ }^{9}$.

Portanto, baseado nesse leading case, foram estabelecidos critérios empregados não só pelo direito americano, mas também pela legislação brasileira a fim de que fique mais inteligível a caracterização de um contrato de investimento coletivo como valor mobiliário.

\subsection{Conceito de "valor mobiliário" no direito brasileiro}

Os órgãos estatais empenham-se, progressivamente, em proteger o investidor; de modo a impor um registro prévio às empresas que apelam à

\footnotetext{
9 Tradução livre de trecho retirado do caso SEC v. H. J. Howey Company: “(...) an investiment contract for purposes of the Securities Act means a contract, transaction or scheme whereby a person invests his money in a common enterprise and is led to expect profits solely from the efforts of the promoter or a third party (...)".
} 
poupança popular para aportar recursos, uma vez que assim haverá o fornecimento de informações para que ocorra uma fiscalização das contas e atos por elas praticados. Essa medida é tomada pois não trata-se apenas de um contrato privado entre partes determinadas, mas sim um contrato em que a outra ponta da relação jurídica é o público em geral.

Muito além de propor uma proteção específica de certo investidor, a nossa legislação busca amparar toda a sociedade, já que, via de regra, os valores mobiliários são ofertados indistintamente.

A partir de então, portanto, cabe ressaltar que o destinatário de valores mobiliários ofertados podem ser de duas espécies distintas, quais sejam: os próprios acionistas em uma emissão privada ou terceiros indeterminados em uma oferta pública.

Ademais, deve-se apontar que há dois modelos de proteção do investidor. Primariamente, existe o modelo europeu, em que cabe à legislação impor os limites e regras de informações que as sociedades devem prestar. Por outro lado, há o sistema americano, em que as leis não são tão rígidas quanto às do velho continente, mas há um órgão estatal visando o controle das companhias, a depender de seu tamanho, tipo de investimento, entre outras características, sem perder de vista a prestação de informações.

Posteriormente, países europeus notaram que uma legislação rígida não era o suficiente para promover a proteção do investidor; então, também a exemplo do sistema norte-americano, criaram órgãos estatais de controle.

É fundamental rememorar, no entanto, que tais regras apenas são aplicadas quando o valor mobiliário é ofertado publicamente, de sorte em que não há respaldo por parte do Estado quando trata-se de valor mobiliário negociado privadamente.

A conceituação de valor mobiliário, contudo, não assegura, por si só, proteção ao investidor, é necessário que o ordenamento jurídico promova garantias informacionais para uma tomada de decisão esclarecida. A 
definição deve ser ampla o suficiente para abranger situações presentes, bem como aquelas que ainda possam surgir.

\subsubsection{Perspectiva legal}

O sistema utilizado no Brasil é o chamado sistema misto, uma vez que estabelece um rol exemplificativo do que se enquadraria como valor mobiliário, bem como, preceitua uma definição ampla para abarcar aqueles contratos que possuem determinados pressupostos, mas ainda não estão expressos de forma especificada.

Embora utilizemos o mesmo sistema de caracterização de valor mobiliário que os norte-americanos, apresentamos mais dificuldades que os nossos vizinhos distantes. Isto porque desde a década de 1930 os tribunais dos Estados Unidos decidem causas relacionadas ao mercado e, assim, vem modelando o que seria a definição mais apropriada de valor mobiliário, diferentemente do que ocorre em solo brasileiro.

Assim, nos Estados Unidos, faz sentido que haja uma sistemática baseada no estabelecimento de pressupostos para que se defina valor mobiliário, uma vez que se trata de mais de oitenta anos de jurisprudência da Suprema Corte Americana em tentar uma consolidação conceitual. Por tal motivo, até hoje mantem-se a definição de valor mobiliário presente nos Act of 1933 e Act of 1934.

O mesmo cenário não é vislumbrado no Brasil, visto que não somos providos de um entendimento, quer seja em âmbito judicial ou administrativo, que permita a criação de uma organização sistemática de valor mobiliário, tal qual nos Estados Unidos.

Assim, nota-se que, legalmente, não há uma definição estrita de valor mobiliário, mas, na verdade, um sistema misto, o qual se utiliza um rol exemplificativo presente nos incisos I a VIII do artigo $2^{\circ}$ da Lei $n^{\circ}$. 
6.385/76 10 , bem como um conceito amplo de contratos de investimento coletivo que, atendidos determinados pressupostos, enquadrar-se-iam como valor mobiliário, disposto no inciso IX do citado artigo ${ }^{11}$.

Importante, ainda, é o papel da doutrina para que seja possível alcançar a tão almejada definição.

Segundo o doutrinador Luiz Gastão Paes de Barros Leães, podem ser considerados valores mobiliários todos os títulos que as sociedades por ações emitem, bem como qualquer tipo de investimento que atendam dois requisitos, são eles: (i) sejam ofertados ao público em geral, para que estes financiem o empreendimento; e (ii) não seja vedado pela lei ${ }^{12}$.

Já Ary Oswaldo Mattos Filho esclarece:

"Para efeito do mercado de capitais, 'valor mobiliário' é o investimento oferecido ao público, sobre o qual o investidor não tem controle direto, cuja aplicação é feita em dinheiro, bens ou serviços, na expectativa de lucro, não sendo necessária a emissão do título para a materialização da relação obrigacional"'13.

Como pode-se notar, não há uma doutrina uníssona quanto ao tema. Contudo, o Colegiado da CVM, através do julgamento do processo RJ

\footnotetext{
${ }^{10}$ Artigo $2^{\circ}$, incisos I a VIII da Lei no . 6.385/76: "São valores mobiliários sujeitos ao regime desta Lei:

I - as ações, debêntures e bônus de subscrição;

II - os cupons, direitos, recibos de subscrição e certificados de desdobramento relativos aos valores mobiliários referidos no inciso II;

III - os certificados de depósito de valores mobiliários;

IV - as cédulas de debêntures;

$V$ - as cotas de fundos de investimento em valores mobiliários ou de clubes de investimento em quaisquer ativos;

VI - as notas comerciais;

VII - os contratos futuros, de opções e outros derivativos, cujos ativos subjacentes sejam valores mobiliários;

VIII - outros contratos derivativos, independentemente dos ativos subjacentes".

${ }^{11}$ Artigo $2^{\circ}$, inciso IX da Lei $\mathrm{n}^{\circ}$. 6.385/76: "IX - quando ofertados publicamente, quaisquer outros títulos ou contratos de investimento coletivo, que gerem direito de participação, de parceria ou de remuneração, inclusive resultante de prestação de serviços, cujos rendimentos advêm do esforço do empreendedor ou de terceiros".

${ }^{12}$ LEÃES, Luiz Gastão Paes de Barros. "O conceito de "security" no direito norteamericano e o conceito análogo no direito brasileiro." Revista de Direito Mercantil, Industrial, Econômico e Financeiro (1974): 41-60. Segundo o jurista, "constituem security os títulos (ações, debêntures, partes beneficiárias) emitidos por uma sociedade por ações. Mas configuram security, também, os investimentos mais diversos, como em gleba de terra, loteamento, empreendimentos rurais, obras de construção civil, títulos de clube etc., desde que os recursos investidos nesses empreendimentos sejam obtidos junto ao público e não haja expressa exclusão legal”.

${ }^{13}$ MATTOS FILHO, Ary Oswaldo. Direito dos valores mobiliários. Volume 1: Tomo 1. Editora $F G V, 2015$, p.188.
} 
11.593 em 2007, estabeleceu parâmetros para apontar se determinado título seria ou não um valor mobiliário, como será visto em tópico a seguir.

\title{
2.2.2. Voto do ex-diretor Marcos Pinto no Processo CVM n. RJ2007/11.593
}

\author{
O referido julgamento foi um marco para entendermos melhor a \\ definição do conceito em pauta. Isto porque o voto do ex-diretor Marcos \\ Barbosa Pinto elucidou as mudanças ocorridas no artigo $2^{\circ}$ da Lei n. $^{\circ}$
} 6.385/76 e como a sua nova redação deveria ser interpretada.

Abaixo, transcreve-se parte do citado voto:

“(...) $2.8 \mathrm{O}$ inciso IX foi claramente inspirado em decisões da Suprema Corte dos Estados Unidos a respeito do conceito de security, em particular, no caso SEC v. W. J. Howey Company . Neste caso, a Suprema Corte decidiu adotar um "princípio flexível e não estático, capaz de se adaptar aos variáveis e incontáveis arranjos criados por aqueles que captam dinheiro de terceiros".

2.9 Segundo a definição que consta em Howey, o conceito de security deve abranger "qualquer contrato, negócio ou arranjo por meio do qual uma pessoa investe seu dinheiro em um empreendimento comum e espera receber lucros originados exclusivamente dos esforcos do empreendedor ou de terceiros".

2.10 Analisando este conceito, a doutrina e a jurisprudencia norte-americanas destacam cinco elementos:

i. para que estejamos diante de um security, uma pessoa deve entregar sua poupanca a outra com o intuito de fazer um investimento;

ii. a natureza do instrumento pelo qual o investimento é formalizado é irrelevante, pouco importando se ele é um título ou contrato ou conjunto de contratos;

iii. o investimento deve ser coletivo, isto é, vários investidores devem realizar um investimento em comum;

iv. o investimento deve ser feito com a expectativa de lucro, cujo conceito é interpretado de maneira ampla, de forma a abarcar qualquer tipo de ganho; e

v. o lucro deve ter origem exclusivamente nos esforcos do empreendedor ou de terceiros, que não o investidor.

2.11 Sem muitas dificuldades, podemos perceber que estas diretrizes encontraram acolhida no inciso IX do art. 2o da Lei no 6.386/76, que estabeleceu os seguintes requisitos para a caracterizacão dos valores mobiliários:

i. deve haver um investimento ("IX - ... quaisquer outros títulos ou contratos de investimento coletivo ...");

ii. o investimento deve ser formalizado por um título ou por um contrato ("IX - ... quaisquer outros títulos ou contratos de investimento coletivo ...");

iii. o investimento deve ser coletivo, isto é, vários investidores devem investir sua poupança no negócio ("IX - ... quaisquer outros títulos ou contratos de investimento coletivo ...");

iv. o investimento deve dar direito a alguma forma de "remuneracão", termo ainda mais amplo que o correlato "lucro" utilizado no direito norte- americano 
("IX - ... títulos ou contratos de investimento coletivo, que gerem direito de participacão, de parceria ou de remuneracẵo ...");

v. a remuneracão deve ter origem nos esforcos do empreendedor ou de terceiros que não o investidor ("IX - ... cujos rendimentos advêm do esforco do empreendedor ou de terceiros"); e

vi. os títulos ou contratos devem ser objeto de oferta pública, requisito que não encontra similar no conceito norte-americano mas que se coaduna perfeitamente com o sistema regulatório dos Estados Unidos ("IX - quando ofertados publicamente, quaisquer outros títulos ...").

2.12 Além destes fatores, que integram o conceito previsto no inciso IX, não podemos esquecer das excecões previstas no $§ 10$ do art. 2o, segundo o qual não são valores mobiliários nem os títulos da dívida pública nem os títulos de responsabilidade das instituicões financeiras. (...)"14.

Por todo o exposto, o melhor caminho a ser seguido, visando a definição de valor mobiliário, é a análise do artigo $2^{\circ}$ da Lei de Mercado de Capitais, e, caso restem dúvidas, recorrer ao voto acima transcrito, visto que esclarece o referido dispositivo legal.

Assim, dentro desse contexto passar-se-á, então, a examinar a evolução do condo-hotel como valor mobiliário, para, finalmente, explorar a regulação de sua oferta pública por parte da Comissão de Valores Mobiliários.

14 CVM n. RJ2007/11.593 (RC n. 5730/2007). Disponível em http://www.cvm.gov.br/export/sites/cvm/decisoes/anexos/0004/5730-0.pdf. Acesso em 02 mar. 2017. 


\section{3. $O$ condo-hotel}

\subsection{Breve histórico do investimento hoteleiro no Brasil}

Antes de deter-se, especificamente, ao instituto do condo-hotel e a regulação de sua oferta pública, importante comentar o processo de desenvolvimento do investimento no ramo da hotelaria brasileira, o qual o condo-hotel está inserido.

O investimento hoteleiro no Brasil apresentou, até hoje, cinco ciclos, segundo José Ernesto Marino Neto ${ }^{15}$, especialista no setor.

O primeiro ciclo ocorreu entre os anos de 1901 e 1964. Essa fase se desenvolveu com o amparo de recursos governamentais da época, bem com o apoio de famílias ricas e empresários que detinham grandes poderes. Com isso, essa fase representou a construção de notáveis edificações, sendo o seu maior representante o Hotel Copacabana Palace, inaugurado em 1923.

A segunda fase se iniciou em 1964 e teve seu fim em 1986. Durante o referido período, houve incentivo fiscal e financeiro às companhias internacionais, que passaram a poder construir suas propriedades com bons financiamentos. O Hotel Rio Othon Palace foi aberto no ano de 1977 e, portanto, um hotel emblemático dessa fase.

Entre os anos de 1986 e 1990 ocorreu o terceiro ciclo. Essa fase caracterizou-se pelo fim dos incentivos fiscais e o advento da Lei $\mathrm{n}^{\circ}$. $8.245 / 91$. Nesse cenário, em que a inflação era a cada dia maior, houve uma freada na construção de imóveis residenciais. Com o novo panorama, surgiu a ideia do "Apart-Hotel", que detinha os atributos de uma unidade de hotel, mas contendo quarto, sala, cozinha, banheiro e pertencer a um condomínio residencial.

O quarto ciclo se inicia em meados de 1994, com a implantação do Plano Real, e tem seu término em 2001. Essa fase se solidificou graças ao

\footnotetext{
${ }^{15}$ Informações obtidas na palestra "Condo-Hotel e a CVM", ministrada por José Ernesto Marino Neto e Paulo Ferreira Dias da Silva em 28.03.2015.
} 
período de estabilidade financeira que o Brasil passava. Isto porque houve incentivo de investimentos produtivos e o ramo hoteleiro passou a ser visto como um negócio atrativo. Dessa forma, os incorporados imobiliários e os administradores de hotelaria uniram-se para criar o chamado "Flat Service".

Este, por sua vez, é caracterizado por ser um quarto de hotel pertencente a um condomínio residencial, em que o "pool de locação" era uma alternativa, isto é, caso consentido, haveria a associação dos proprietários dos quartos que, conjuntamente à uma administradora hoteleira, poderiam oferecer suas unidades para locação na roupagem de apartamento de hotel e, assim, receberiam os seus rendimentos.

A partir do ano de 2001, porém, os empresários perceberam que o último ciclo originou mais quartos que a demanda necessitava, havendo, assim, uma crise no ramo imobiliário, o que culminou em uma super oferta.

A referida crise teve algumas consequências, tais quais: renegociações contratuais, visando reduzir as taxas de administração e os prazos dos contratos; o aparecimento de novas empresas administradoras hoteleiras; a saída generalizada do "Apart-Hotel" do mercado hoteleiro, uma vez que muitos foram revertidos em unidades residenciais; a criação do FOHB - Fórum de Operadores Hoteleiros no Brasil no ano de 2002, entre outras.

Assim, nesse cenário, o mercado imobiliário presenciou uma recessão. Contudo, com o avanço da economia nos dez anos seguintes, houve, novamente, o progresso desse mercado, estabelecendo, portanto, o começo do quinto ciclo.

A referida fase experimentou o seu início em 2011 e perdura até hoje. Tal ciclo representa o advento do chamado condo-hotel, como será exposto em tópico que segue.

\subsection{Conceito de "condo-hotel" no Brasil}


O termo "condo-hotel" é originado da expressão "hotelcondomínio", uma vez que ele detém características tanto de um empreendimento hoteleiro quanto de um condomínio residencial.

Os primeiros condo-hotéis surgiram na década de 1970 nos Estados Unidos e, brevemente, tornaram-se muito atrativos. Contudo, eles apenas passaram a ter sua onda de popularidade no Brasil algumas décadas depois.

Com o progresso da economia no país, vinculada à necessidade de construção de quartos para hospedar os turistas e atletas atraídos pelos eventos esportivos que o Brasil iria sediar, os condo-hotéis passaram a se revelar um ótimo investimento.

O condo-hotel pode ser entendido como um empreendimento imobiliário em que todos os seus quartos ou parte deles foram transformados legalmente em unidades condominiais.

Tais unidades, por sua vez, são ofertadas e vendidas a compradores que não detêm a sua posse, na medida em que seus proprietários fazem parte do chamado "pool de locação", isto é, a associação dos condôminos que, juntamente à gerência do próprio hotel, destinam suas unidades à locação para terceiros.

Importante salientar, dessa forma, a principal característica dos condo-hotéis, que os difere de todos os empreendimentos imobiliários dos ciclos anteriores, qual seja, a obrigatoriedade de participação no "pool de locação". Sua maior atribuição, portanto, é a impossibilidade de moradia ou locação independente por parte do proprietário. Isto porque os detentores das unidades imobiliárias são obrigados a participar do referido pool, ou seja, os seus apartamentos serão designados, exclusivamente, à exploração hoteleira.

O condo-hotel, embora amplamente visto como um investimento, é, sobretudo, um meio de hospedagem, como caracteriza o artigo 23 caput e $\S^{\circ}$ da Lei $n^{\circ}$. 11.771/08 (Lei Geral do Turismo), abaixo transcritos:

"Art. 23. Consideram-se meios de hospedagem os empreendimentos ou estabelecimentos, independentemente de sua forma de constituição, destinados a 
prestar serviços de alojamento temporário, ofertados em unidades de frequência individual e de uso exclusivo do hóspede, bem como outros serviços necessários aos usuários, denominados de serviços de hospedagem, mediante adoção de instrumento contratual, tácito ou expresso, e cobrança de diária.

$\S 3^{\circ}$ Não descaracteriza a prestação de serviços de hospedagem a divisão do empreendimento em unidades hoteleiras, assim entendida a atribuição de natureza jurídica autônoma às unidades habitacionais que o compõem, sob titularidade de diversas pessoas, desde que sua destinação funcional seja apenas e exclusivamente a de meio de hospedagem".

Ademais, cabe ressaltar que, segundo o artigo 24, inciso II, alínea b da Lei $n^{\circ}$. 11.771/08, para que o condo-hotel tenha seu cadastramento efetuado perante o Ministério do Turismo é necessário que haja um contrato ou documento que oficialize a instituição do "pool de locação". A seguir transcreve-se o citado dispositivo:

"Art. 24. Os meios de hospedagem, para obter o cadastramento, devem preencher pelo menos um dos seguintes requisitos:

(...)

II - no caso dos empreendimentos ou estabelecimentos conhecidos como condomínio hoteleiro, flat, flat-hotel, hotel-residence, loft, apart-hotel, apartservice condominial, condohotel e similares, possuir licença edilícia de construção ou certificado de conclusão de construção, expedidos pela autoridade competente, acompanhados dos seguintes documentos:

(...)

b) documento ou contrato de formalização de constituição do pool de locação, como sociedade em conta de participação, ou outra forma legal de constituição, com a adesão dos proprietários de pelo menos $60 \%$ (sessenta por cento) das unidades habitacionais à exploração hoteleira do empreendimento".

Dessa maneira, inferimos que o condo-hotel, para subsistir, necessita da instauração do "pool de locação", que, como já exposto, é a reunião dos proprietários dos apartamentos (ou sua fração) de empreendimento imobiliário que designam sua unidade para serem explorados como se quarto de hotéis fossem.

Cabe ressaltar que a associação acima mencionada inclui tanto os quartos, quanto as áreas e bens comuns do empreendimento, tais quais seus equipamentos, instalações, piscina, área de lazer, entre outros.

Portanto, condo-hotel pode ser entendido como um hotel, cuja unidades (todas ou 60\%, no mínimo) são comercializadas a terceiros, os quais assinam contrato com a administradora hoteleira pactuando que as 
referidas unidades não darão direito de uso a seus donos, mas, na verdade, serão destinadas a locação para terceiros, na roupagem de quarto de hotel.

\subsection{Agentes do mercado condo-hoteleiro}

Para que o funcionamento do mercado de condo-hotéis ocorra de forma próspera são necessários alguns agentes; contudo, antes de analisálos, importante observar a definição de condo-hotel dada pela Comissão de Valores Mobiliários, abaixo transcrita:

"Condo-hotel é uma modalidade de exploração da atividade econômica hoteleira. Na prática é um hotel em que a propriedade é compartilhada por um condomínio de investidores, que financiam conjuntamente o projeto e são remunerados, na proporção que couber a cada um, pelos resultados operacionais do empreendimento administrado por um operador hoteleiro" 16 .

A partir da citada conceituação, infere-se que o condo-hotel pode ser visto sob duas perspectivas distintas. Por um lado, pela visão de empreendedores, é um instrumento que viabiliza o projeto, na medida em que torna-se uma modalidade de atração de investidores para financiar a construção do empreendimento.

Sob outra ótica, há o lado daqueles que empregam seus recursos no empreendimento, isto é, os investidores. Eles apenas financiam o projeto com o objetivo de rentabilizar o seu dinheiro, uma vez que não poderão fazer uso de sua propriedade imobiliária.

Dessa forma, pode-se concluir que o mercado de condo-hotéis envolve alguns personagens, os quais serão vistos a seguir.

$\mathrm{O}$ primeiro ator que merece destaque nesse mercado é a incorporadora hoteleira. Isto porque ela é a responsável pelo planejamento, projeto e o lançamento do hotel. Ademais, cabe a ela promover e comercializar o empreendimento, apesar de ser usual a contratação de corretoras imobiliárias visando a intermediação da venda dos quartos para o

\footnotetext{
${ }^{16}$ Informação extraída do " $8^{\circ}$ Boletim de Proteção do Consumidor / Investidor", disponível em http://www.portaldoinvestidor.gov.br/portaldoinvestidor/export/sites/portaldoinvestidor/publicaca o/Boletim/BoletimCVMSENACON-8.pdf. Acesso em 15 abr. 2017.
} 
público. Ela tem, ainda, a atribuição de construir o hotel, podendo delegar tal função a uma construtora, se conveniente.

Além dos atributos acima descritos, a incorporadora é amplamente atuante desde o início da oferta de distribuição do empreendimento aos investidores até a conclusão das obras do hotel. E é responsável, por fim, pela questão regulatória do condo-hotel.

O segundo participante desse mercado é a corretora imobiliária (ou corretores de imóveis). Esse agente pode ser representado por uma empresa ou grupo de profissionais contratados para promover a apresentação e venda das unidades autônomas do empreendimento aos possíveis investidores interessados no negócio.

Seu ofício é um dos mais importantes para a prosperidade do mercado de condo-hotel, dado que promove a intermediação do empreendimento com os investidores. Importante ressaltar, ainda, que sua remuneração é comumente vinculada ao seu desempenho, uma vez que recebem uma porcentagem das vendas efetuadas.

O terceiro personagem que merece atenção é o operador hoteleiro. Sua função é indispensável, visto que operaciona o empreendimento após a sua construção e venda, além de ser responsável por administrar o hotel em seu funcionamento diário. Possui, ainda, o encargo de apresentar a prestação de contas e distribuição do resultado aos investidores.

Para a prestação de tais serviços, o operador hoteleiro, em geral, é remunerado por uma porcentagem sobre as receitas do empreendimento. Assim, pode-se destacar que, após a conclusão da construção do hotel, é o agente mais atuante, não sendo descartada sua participação antes da entrega das obras, dado que é responsável, também, pela oferta do empreendimento.

Por fim, o último ator do mercado de condo-hotel é o investidor ou condômino. Ele é quem assina os contratos de investimento coletivo em condo-hotéis e pode ser pessoa física ou jurídica. Sua atribuição é essencial para o funcionamento de todo esse sistema, uma vez que é responsável por empregar seus recursos e, assim, financiar o empreendimento. Em 
contrapartida, o investidor recebe o direito de participar dos resultados oriundos da exploração mercantil do hotel.

Ademais, é relevante apontar que, em alguns casos, são contratados os chamados "asset managers", ou seja, profissionais especializados em fiscalizar o empreendimento, atuando como um representante dos condôminos.

Portanto, uma vez analisados os participantes no mercado de condohotel passar-se-á, então, a estudar como ocorre o seu funcionamento.

\subsection{Funcionamento dos empreendimentos condo-hoteleiros}

Os investidores, visando a sua participação em um empreendimento condo-hoteleiro, assinam um conjunto de contratos, os quais, a depender de suas características, irão demarcar o tipo de investimento. Cabe ressaltar que tal grupo de contratos é conhecido, no mercado financeiro, por contrato de investimento coletivo (CIC) em condo-hotéis.

$\mathrm{Na}$ prática, os referidos contratos podem espelhar dois modelos distintos de investimento hoteleiro, são eles: o empreendimento constituído por unidades autônomas e a edificação composta por frações ideais de condomínios gerais. Assim, os contratos podem ter aspectos próprios, o que resultará nesses diferentes modelos de CIC.

O tipo mais usual é aquele que comercializa unidades imobiliárias autônomas em um condomínio edilício tradicional. Nesse caso, os condôminos passam a ser possuídores de unidades que são registradas e matriculadas no Registro Geral de Imóveis (RGI), e a sua aquisição, para ser efetuada, deve atender aos requisitos da Lei $\mathrm{n}^{\circ}$. 4.591/64 (Lei de Condomínio e Incorporações), como a compra de qualquer outro imóvel.

O contrato de compra e venda da unidade hoteleira está incluso entre os contratos que compõem os CIC e, assim, deve ser prontamente assinado caso o investidor queira adquirir determinada unidade. 
Os CIC viabilizam que a operadora hoteleira passe a administrar comercialmente as unidades, uma vez que será responsável pela administração do empreendimento pelo prazo contratualmente pactuado. Nesse interim, é comum que os condôminos sejam proibidos de usar e fruir de suas unidades, apenas em algumas raras ocasiões é possível que eles possam usufruir de sua propriedade.

Dessa forma, a partir do momento em que as unidades autônomas passam a fazer parte do "pool de locação", elas são administradas pela empresa hoteleira contratada e o investidor fica preso às suas decisões, como apontado pela Comissão de Valores Mobiliários:

"Na prática isso significa dizer que o investidor não tem a liberdade de morar, emprestar ou mesmo alugar a sua unidade de forma isolada, como em geral é possível no investimento tradicional em imóveis". ${ }^{17}$

Assim, para que tal sistema seja viabilizado, é comum que dentre os CIC, seja assinado um Contrato de Sociedade em Conta de Participação $(\mathrm{SCP})^{18}$. Isto porque, a partir dele, fica contratualmente estabelecida uma sociedade visando a administração das unidades autônomas. Sendo ela composta pela operadora hoteleira, que ocupa o cargo de sócia-ostensiva, bem como pelos investidores/condôminos, os quais tornam-se sócios ocultos.

Os adquirentes das unidades hoteleiras, portanto, terão direito de receber sua parte nos resultados do investimento de acordo com a sua proporção, a qual, em regra, é correspondente à sua fração ideal no empreendimento.

\subsection{Condo-hotel como valor mobiliário}

17 " $8^{\circ}$ Boletim de Proteção do Consumidor / Investidor", disponível em http://www.portaldoinvestidor.gov.br/portaldoinvestidor/export/sites/portaldoinvestidor/publicaca o/Boletim/BoletimCVMSENACON-8.pdf. Acesso em 15 abr. 2017.

${ }_{18}$ Os artigos 991 a 996 da Lei $n^{\circ}$. 10.406/2002 (Código Civil) regulam as Sociedades em Conta de Participação. 
O condo-hotel, embora possua características comuns do mercado imobiliário, não pode ser tratado como um simples investimento direto em imóveis, tal qual é difundido em nossa cultura. Isto porque o seu modelo de exploração econômica é muito similar a uma atividade mercantil e, por isso, uma vez ofertado, pode assumir a feição de investimento financeiro.

Assim, muito além de representar apenas um valor imobiliário, pois estamos tratando da comercialização de imóveis, os condo-hotéis representam, também, uma espécie de valor mobiliário, pelos motivos a seguir expostos.

Primeiramente, cabe ressaltar que, em geral, a comercialização dos condo-hotéis é procedida enquanto os imóveis ainda encontram-se na planta, ou seja, há apenas o seu projeto e nada construído. Essa é uma importante característica, pois, a partir dela, pode-se inferir que os compradores investirão seus recursos para financiar a edificação daquele empreendimento.

Então, os ofertantes do imóvel buscam investidores que empregarão seu dinheiro na construção do hotel e, a partir de então, quando todo o recurso necessário for angariado, as obras se iniciarão.

Naturalmente, os novos condôminos esperam receber alguma contrapartida ao investimento aportado. Contudo, diferentemente da compra de um imóvel comum, os seus proprietários não recebem o direito de usar, fruir, gozar e dispor de sua unidade hoteleira, dado que os investidores passam a fazer parte do chamado "pool de locação" e as suas unidades são administradas por uma operadora hoteleira.

Dessa forma, não é possível confundir condo-hotel com um simples imóvel, uma vez que ele não pode ser considerado uma residência, já que não dá direito de uso ao seu proprietário. Assim, a contrapartida que o condômino espera é um rendimento oriundo da locação de sua unidade imobiliária. 
A partir dos aspectos acima enunciados, resta claro que trata-se de um investimento. Contudo, para ele ser considerado valor mobiliário, é necessário que sejam atendidos outros requisitos.

Como visto em capítulo anterior, para identificar determinado título como valor mobiliário, é indispensável a análise do inciso IX do artigo $2^{\circ}$ da Lei $\mathrm{n}^{\mathrm{o}}$. 6.385/76. Conforme o citado dispositivo, podem ser considerados valores mobiliários, desde que publicamente ofertados:

“(...) quaisquer outros títulos ou contratos de investimento coletivo, que gerem direito de participação, de parceria ou de remuneração, inclusive resultante de prestação de serviços, cujos rendimentos advêm do esforço do empreendedor ou de terceiros".

Assim, observa-se que condo-hotel, uma vez ofertado indistintamente, pode, de fato, ser enquadrado como valor mobiliário, dado que apresenta as características acima apontadas. Isto porque ele é viabilizado por contratos coletivos, os quais são assinados por investidores que aplicam seus recursos visando participação nos resultados oriundos da locação de suas respectivas unidades. Nesse sentido, esclarece a CVM:

\footnotetext{
"O ponto é que os CICs em condo-hotéis ofertados no mercado apresentam todas as características de um valor mobiliário (...). De fato, se observamos, esses contratos coletivos oferecem aos investidores uma alternativa para investirem seus recursos financeiros, na expectativa de participar dos resultados obtidos na exploração do empreendimento, que é administrado por um terceiro, o operador hoteleiro" ${ }^{\prime 19}$.
}

Tendo em vista, portanto, que condo-hotel trata-se de valor mobiliário, sua oferta pública deve ser regulada pela CVM, como será visto a seguir.

\footnotetext{
19 Trecho extraído do "8º Boletim de Proteção do Consumidor / Investidor", disponível em http://www.portaldoinvestidor.gov.br/portaldoinvestidor/export/sites/portaldoinvestidor/publicaca o/Boletim/BoletimCVMSENACON-8.pdf. Acesso em 15 abr. 2017.
} 


\section{CVM e a oferta pública de distribuição de valores mobiliários}

\subsection{Atribuições e poderes da CVM}

$\mathrm{O}$ artigo $5^{\circ}$ da Lei $\mathrm{n}^{\mathrm{o}}$. 6.385/76 ${ }^{20}$ estabelece que a Comissão de Valores Mobiliários é entidade autárquica em regime especial, a qual detém autoridade administrativa independente, bem como autonomia financeira e orçamentária.

O campo de atuação e competência da autarquia está estabelecido no artigo $1^{\circ}$ da Lei $n^{\circ}$. 6.385/76 21 . Segundo o citado dispositivo, compete à CVM disciplinar e fiscalizar as questões concernentes a (i) emissão e distribuição de valores mobiliários no mercado; (ii) negociação e intermediação no mercado de valores mobiliários; (iii) negociação e intermediação no mercado de derivativos; (iv) organização, o funcionamento e as operações das Bolsas de Valores; (v) organização, o funcionamento e as operações das Bolsas de Mercadorias e Futuros; (vi) administração de carteiras e a custódia de valores mobiliários; (vii) auditoria das companhias abertas; e (viii) serviços de consultor e analista de valores mobiliários.

Considerando tais competências da CVM, pode-se afirmar que a autarquia possui, sobretudo, três funções no mercado de capitais, são elas: fiscalizar, normatizar e, principalmente, regular.

\footnotetext{
${ }^{20}$ Artigo $5^{\circ}$ da Lei $\mathrm{n}^{\circ}$. 6.385/76: "É instituída a Comissão de Valores Mobiliários, entidade autárquica em regime especial, vinculada ao Ministério da Fazenda, com personalidade jurídica e patrimônio próprios, dotada de autoridade administrativa independente, ausência de subordinação hierárquica, mandato fixo e estabilidade de seus dirigentes, e autonomia financeira e orçamentária".

${ }^{21}$ Artigo $2^{\circ}$ da Lei $n^{\circ}$. 6.385/76: "Serão disciplinadas e fiscalizadas de acordo com esta Lei as seguintes atividades:

I - a emissão e distribuição de valores mobiliários no mercado;

II - a negociação e intermediação no mercado de valores mobiliários;

III - a negociação e intermediação no mercado de derivativos;

IV - a organização, o funcionamento e as operações das Bolsas de Valores;

$V$ - a organização, o funcionamento e as operações das Bolsas de Mercadorias e Futuros;

VI - a administração de carteiras e a custódia de valores mobiliários;

VII - a auditoria das companhias abertas;

VIII - os serviços de consultor e analista de valores mobiliários".
} 
Antes de abordar cada uma dessas atribuições, importante destacar o papel da autarquia no que diz respeito à proteção dos investidores, uma vez que a regulação do mercado de capitais brasileiro baseia-se na política do full disclosure, a exemplo do modelo norte-americano.

Tal política consiste na prestação de informações completas, verdadeiras e atuais pelas companhias abertas acerca delas próprias e seus valores mobiliários ofertados publicamente. Isto porque os possíveis investidores, desse modo, poderão tomar suas decisões de investimento de forma clara e precisa.

Nesse sentido, Julio Dubeux esclarece:

"A regulação da divulgação de informações visa a assegurar ao público a disponibilidade, em tempo hábil, de forma eficiente e razoável, de informações necessárias para a tomada de decisão de investir em valores mobiliários"22.

Para que o mercado de capitais funcione com sua máxima eficiência, é necessário o respeito da política do full disclosure. Assim, visando a sua observância, todas as atribuições da CVM tem como finalidade precípua a proteção do investidor.

A primeira função da autarquia que merece destaque é a fiscalizatória. Segundo o artigo $8^{\circ}$, inciso III da Lei $6.385 / 76^{23}$, a CVM deve fiscalizar as atividades, os serviços, a veiculação de informações, os valores e os agentes do mercado de valores mobiliários.

O papel fiscalizador da autarquia também se concretiza através do registro das companhias abertas e suas respectivas emissões e distribuições, além da exigência de divulgação de informações ao mercado.

22 DEBEUX, Julio R, A Comissão de Valores Mobiliários e os principais instrumentos regulatórios do mercado de capitais brasileiro. Porto Alegre. Sergio Antonio Fabris Ed., 2006, p. 44.

${ }^{23}$ Artigo 8, inciso III da Lei no . 6.385/76: "Compete à Comissão de Valores Mobiliários:

III - fiscalizar permanentemente as atividades e os serviços do mercado de valores mobiliários, de que trata o Art. $1^{\circ}$, bem como a veiculação de informações relativas ao mercado, às pessoas que dele participem, e aos valores nele negociados;". 
O órgão regulador possui, ainda, poder punitivo, como expresso no artigo 11 da Lei de Mercado de Capitais ${ }^{24}$. É atribuída à CVM a função de apurar, julgar e punir condutas contrárias ao mercado de valores mobiliários.

Há, ainda, as atribuições de regulação e normatização por parte da autarquia, que devem ser expostas em conjunto, uma vez que são complementares.

A função regular está fundada no inciso I do artigo $8^{\circ}$ da Lei $n^{\circ}$. $6.385 / 76^{25}$ e a CVM executa a citada função por meio da edição de Instruções Normativas e Deliberações, as quais regulam as determinações expressas tanto na Lei de Mercado de Capitais quanto na Lei das S.A., devendo tais exigências ser atendidas pelos agentes do mercado.

Cabe à CVM regular os temas presentes nas referidas leis, sendo tal atribuição concretizada a partir da edição de normas internas que possuem caráter obrigacional aos agentes do mercado de capitais. Portanto, para que o papel regulador da autarquia se viabilize, importante é o seu caráter normativo.

Tendo em vista as atribuiçõos dadas à CVM, entende-se que a mesma é competente por fiscalizar, regular e normatizar os assuntos presentes nas Leis $n^{\circ} 6.385 / 76$ e 6.404/76, dentre os quais, por ser o tema

\footnotetext{
${ }^{24}$ Artigo 11 da Lei no. 6.385/76: "A Comissão de Valores Mobiliários poderá impor aos infratores das normas desta Lei, da lei de sociedades por ações, das suas resoluções, bem como de outras normas legais cujo cumprimento lhe incumba fiscalizar, as seguintes penalidades:

I - advertência;

II - multa;

III - suspensão do exercício do cargo de administrador ou de conselheiro fiscal de companhia aberta, de entidade do sistema de distribuição ou de outras entidades que dependam de autorização ou registro na Comissão de Valores Mobiliários;

IV - inabilitação temporária, até o máximo de vinte anos, para o exercício dos cargos referidos no inciso anterior;

$V$ - suspensão da autorização ou registro para o exercício das atividades de que trata esta Lei; VI - cassação de autorização ou registro, para o exercício das atividades de que trata esta Lei; VII - proibição temporária, até o máximo de vinte anos, de praticar determinadas atividades ou operações, para os integrantes do sistema de distribuição ou de outras entidades que dependam de autorização ou registro na Comissão de Valores Mobiliários;

VIII - proibição temporária, até o máximo de dez anos, de atuar, direta ou indiretamente, em uma ou mais modalidades de operação no mercado de valores mobiliários".

${ }^{25}$ Artigo $8^{\circ}$ da Lei n ${ }^{\circ}$. 6.385/76: "Compete à Comissão de Valores Mobiliários:

I - regulamentar, com observância da política definida pelo Conselho Monetário Nacional, as matérias expressamente previstas nesta Lei e na lei de sociedades por ações;"”.
} 
do presente trabalho, destacamos as ofertas públicas de distribuição de valores mobiliários, como será visto a seguir.

\subsection{Oferta pública de distribuição valores mobiliários}

\subsubsection{Conceito}

Oferta pública de distribuição de valores mobiliários é a operação mediante a qual se promove a colocação de valores mobiliários das companhias abertas no mercado de capitais, de modo a possibilitar que os investidores interessados em tornarem-se titulares dos papéis ofertados possam subscrevê-los ou adquiri-los, mediante o pagamento por eles efetuado ao ofertante.

Oferta pública de valores mobiliários, de acordo com a CVM, pode ser entendida como:

“(...) o processo de colocação, junto ao público, de um certo número de títulos e valores mobiliários para venda. Envolve desde o levantamento das intenções do mercado em relação aos valores mobiliários ofertados até a efetiva colocação junto ao público, incluindo a divulgação de informações, o período de subscrição, entre outras etapas" 26 .

A oferta pública divide-se em duas espécies, são elas: oferta primária ou secundária. A primeira categoria é verificada quando a companhia emite novos valores mobiliários ao mercado, a fim de captar investidores para a execução de projetos ou adequação do passivo.

Oferta pública primária pode ser caracterizada da seguinte forma, conforme entendimento da CVM:

"Quando a empresa vende títulos novos, operação conhecida como "emissão de ações", os recursos dessa venda são destinadas ao caixa da empresa e as ofertas são chamas de primárias, constituindo um aumento no capital social" ${ }^{\prime 27}$.

\footnotetext{
26 Informação extraída do "Portal do investidor", disponível em http://www.portaldoinvestidor.gov.br/menu/Menu_Investidor/ofertas/ofertas_publicas.html. Acesso em 23 de abr. 2017.

27 O mercado de valores mobiliários brasileiro / Comissão de Valores Mobiliários. 3. ed. Rio de Janeiro: Comissão de Valores Mobiliários, 2014. 217 p.
} 
Cabe apontar, ainda, que a primeira oferta pública de uma companhia, isto é, aquela que representa a sua abertura de capital é chamada de oferta pública inicial ou IPO (Inicial Public Offer, do inglês). Ao passo que as emissões subsequentes de uma companhia que já possui o seu capital aberto são chamadas de follow on.

Na oferta pública secundária, há uma relação "investidor-investidor" no que diz respeito à comercialização de valores mobiliários já emitidos pela companhia. Isto porque, nesse tipo de oferta, os investidores que subscreveram o valor mobiliário emitido pela sociedade agora irão renegociá-lo no mercado de capitais com outro investidor. Essa espécie de oferta pública pode ser observada quando um ou mais acionistas da sociedade ou titulares de outros valores mobiliários de sua emissão vendem os títulos de sua propriedade, não havendo, assim, a emissão de novos papéis.

Todas as ofertas públicas, bem como outros atos realizados pelas companhias abertas, devem ser levados a registro na $\mathrm{CVM}^{28}$. Isso ocorre para tornar públicas certas informações que podem vir a ser relevantes para os investidores, de modo a proteger os seus interesses e tornar consciente a sua tomada de decisão. E, portanto, garantir a observância ao full disclosure.

É necessário ressaltar que a CVM apenas normatiza as ofertas públicas de valores mobiliários, ao passo que as ofertas privadas ou particulares não estão no âmbito de atuação da autarquia. Isto porque a CVM busca proteger a poupança popular, algo alheio às ofertas particulares ou privadas.

A Lei de Mercado de Capitais, contudo, não se preocupou em conceituar oferta pública, tampouco a privada, mas o artigo $19, \S 3^{\text {o29 }}$ da

\footnotetext{
${ }^{28}$ Como será abordado no tópico 4.2.2 do presente trabalho.

${ }^{29}$ Artigo $19, \S 3^{\circ}$ da Lei no. 6.385/76: "Caracterizam a emissão pública:

I - a utilização de listas ou boletins de venda ou subscrição, folhetos, prospectos ou anúncios destinados ao público;

II - a procura de subscritores ou adquirentes para os títulos por meio de empregados, agentes ou corretores;
} 
citada lei indicou determinadas práticas que, uma vez vislumbradas, poderiam caracterizar uma oferta como pública, tais quais: utilizar listas, boletins, folhetos ou anúncios destinados ao público; negociação feita em estabelecimento aberto ao público, dentre outros.

A Instrução CVM no 400/2003 incorporou tais indicações e passou a estabelecer, no caput do seu artigo $3^{\circ}$, atos considerados como oferta pública de valores mobiliários, como pode-se verificar abaixo:

\begin{abstract}
“Artigo $3^{\circ}$. São atos de distribuição pública a venda, promessa de venda, oferta à venda ou subscrição, assim como a aceitação de pedido de venda ou subscrição de valores mobiliários, de que conste qualquer um dos seguintes elementos:

I - a utilização de listas ou boletins de venda ou subscrição, folhetos, prospectos ou anúncios, destinados ao público, por qualquer meio ou forma;

II - a procura, no todo ou em parte, de subscritores ou adquirentes indeterminados para os valores mobiliários, mesmo que realizada através de comunicações padronizadas endereçadas a destinatários individualmente identificados, por meio de empregados, representantes, agentes ou quaisquer pessoas naturais ou jurídicas, integrantes ou não do sistema de distribuição de valores mobiliários, ou, ainda, se em desconformidade com o previsto nesta Instrução, a consulta sobre a viabilidade da oferta ou a coleta de intenções de investimento junto a subscritores ou adquirentes indeterminados;

III - a negociação feita em loja, escritório ou estabelecimento aberto ao público destinada, no todo ou em parte, a subscritores ou adquirentes indeterminados; ou IV - a utilização de publicidade, oral ou escrita, cartas, anúncios, avisos, especialmente através de meios de comunicação de massa ou eletrônicos (páginas ou documentos na rede mundial ou outras redes abertas de computadores e correio eletrônico), entendendo-se como tal qualquer forma de comunicação dirigida ao público em geral com o fim de promover, diretamente ou através de terceiros que atuem por conta do ofertante ou da emissora, a subscrição ou alienação de valores mobiliários" (grifamos).
\end{abstract}

A partir da leitura do citado dispositivo nota-se que a CVM utiliza apenas critérios objetivos para a caracterização das ofertas públicas. E, para melhor entender o disposto na referida redação, o $\$ 1^{\circ}$ do $\operatorname{artigo} 3^{\circ}$ da Instrução CVM $\mathrm{n}^{\circ}$. 400/2003 esclarece quem pode ser considerado destinatário de tais ofertas:

“ $§ 1^{\circ}$ Para efeito desta Instrução, considera-se como público em geral uma classe, categoria ou grupo de pessoas, ainda que individualizadas nesta qualidade, ressalvados aqueles que tenham prévia relação comercial, creditícia, societária ou trabalhista, estreita e habitual, com a emissora".

III - a negociação feita em loja, escritório ou estabelecimento aberto ao público, ou com a utilização dos serviços públicos de comunicação". 
Embora a autarquia apenas utilize critérios objetivos para a determinação das ofertas públicas, Nelson Eizirik entende existir também um critério subjetivo, o qual deve levar em consideração a qualificação dos investidores e a sua possibilidade de conhecimento de informações sobre a companhia.

De acordo com o jurista:

"Em regra, considera-se que a possibilidade de acesso a tais informações pode ser presumida caso os ofertados possuam alguma espécie de vínculo com a companhia emissora, o qual pode decorrer de fatores como relações familiares, de amizade de emprego ou de negócios com a emissora". ${ }^{30}$

Isto posto, para uma oferta de distribuição de valores mobiliários ser classificada como pública, todas as suas circunstâncias fáticas devem ser consideradas, analisando os seus critérios objetivos, de modo a identificar se o propósito da oferta era alcançar um número indiscriminado de pessoas para se tornarem possíveis investidores.

Portanto, uma vez esclarecidos os aspectos de uma oferta pública de distribuição de valores mobiliários, cabe agora estudar como ocorre o seu registro (ou sua dispensa), bem como a Instrução Normativa que a regula, qual seja, a Instrução CVM nº. 400/2003.

\subsubsection{Registro e a Instrução CVM n. $400 / 2003$}

As ofertas públicas de distribuição de valores mobiliários estão dispostas em lei e são regulamentadas pela Comissão de Valores Mobiliários, já que envolvem a captação de recursos da poupança popular. O intuito é possibilitar a todos os investidores a participação equitativa em uma oferta pública.

De acordo com o estabelecido no artigo 19 da Lei $n^{\circ} .6 .385 / 76^{31}$ e no artigo $4^{\circ}, \S 2^{\circ}$ da Lei $n^{\circ} .6 .404 / 76^{32}$, todas as emissões públicas apenas

\footnotetext{
${ }^{30}$ EIZIRIK, Nelson et al. Mercado de Capitais - Regime Jurídico. $3^{\mathrm{a}}$ ed. Revista e ampliada - Rio de Janeiro: Renovar, 2011. p. 154.

${ }^{31}$ Artigo 19, caput da Lei $\mathrm{n}^{\circ}$. 6.385/76: "Nenhuma emissão pública de valores mobiliários será distribuída no mercado sem prévio registro na Comissão".
} 
poderão ser distribuídas no mercado após prévio registro na Comissão de Valores Mobiliários. Entretanto, em alguns casos, a autarquia possui a prerrogativa de dispensar o referido registro.

Visando a regulamentação e disciplina das ofertas públicas de emissão de valores mobiliários, portanto, a Comissão de Valores Mobiliários editou a Instrução CVM nº. 400, de 29 de dezembro de 2003.

A citada instrução é a responsável por regular as ofertas públicas de distribuição de valores mobiliários nos mercados primário ou secundário e assegurar, ainda, a proteção dos interesses do público investidor e do mercado em geral.

\section{Segundo a Comissão de Valores Mobiliários:}

"A instrução CVM 400/03, que disciplina as ofertas públicas de valores mobiliários os mercados primários e secundários, estabelece situações de obrigatoriedade do registro, casos de dispensa e aspectos relacionados à informação, ao sistema de distribuição, ao recebimento de reservas e às normas de conduta, entre outros" ${ }^{\prime 3}$.

O pedido de registro de oferta pública de valores mobiliários deve ser submetido à CVM pela instituição líder da distribuição (underwriter) ${ }^{34} \mathrm{e}$ pelo ofertante emissor, os quais devem apresentar as informações e os documentos previstos no artigo $7^{035}$ e Anexo II $^{36}$ da Instrução CVM n . 400/2003, para que o full disclosure seja observado.

\footnotetext{
${ }^{32}$ Artigo $4^{\circ}, \S^{\circ}$ da Lei $n^{\circ}$. 6.404/76: “Nenhuma distribuição pública de valores mobiliários será efetivada no mercado sem prévio registro na Comissão de Valores Mobiliários".

${ }^{33} \mathrm{O}$ mercado de valores mobiliários brasileiro / Comissão de Valores Mobiliários. 3. ed. Rio de Janeiro: Comissão de Valores Mobiliários, 2014. 215 p.

${ }^{34}$ Toda oferta pública precisa ser coordenada por instituição integrante do sistema de distribuição de valores mobiliários, tais quais corretoras, bancos de investimento ou distribuidoras. Na hipótese de haver mais de uma instituição financeira, a principal será escolhida para tratar dos procedimentos da distribuição e será denominada como instituição líder. Ver DEBEUX, Julio R. Op. cit., p. 66.

${ }^{35}$ Artigo $7^{\circ}$ da Instrução $\mathrm{CVM} \mathrm{n}$. 400/2003: "O pedido de registro de oferta pública de distribuição de valores mobiliários será requerido à CVM pelos fundadores ou pelo ofertante, conforme o caso, em conjunto com a instituição líder da distribuição, e deverá ser instruído com os documentos e informações constantes do Anexo II, em forma de minuta, preliminar ou final, conforme o caso".

${ }^{36}$ Anexo II da Instrução CVM no. 400/2003: "ANEXO II - DOCUMENTOS E INFORMAÇÕES EXIGIDOS PARA O REGISTRO

1. contrato de distribuição de valores mobiliários, do qual deverá constar, entre outras, obrigatoriamente, as cláusulas relacionadas no Anexo VI, e respectivos termos aditivos ou de adesão;
} 
2. contratos de estabilização de preços elou de garantia de liquidez, se houver, que deverá ser objeto de aprovação da CVM;

3. outros contratos relativos à emissão ou subscrição, inclusive no que toca à distribuição de lote suplementar, se houver;

4. modelo de boletim de subscrição ou recibo de aquisição, o qual deverá conter, obrigatoriamente:

a) previsão para identificação de sua numeração;

b) espaço para a assinatura do subscritor ou adquirente;

c) condições de integralização, subscrição ou aquisição de sobras, se for o caso; $e$

d) declaração do subscritor ou adquirente de haver obtido exemplar do Prospecto Definitivo.

5. um exemplar da minuta do Prospecto Definitivo ou um exemplar do Prospecto Preliminar e, quando disponível, um exemplar da versão final do Prospecto Definitivo, que conterão, no mínimo, as informações exigidas pela CVM (Anexo III);

6. cópia da deliberação sobre a aprovação de programa ou sobre a emissão ou distribuição dos valores mobiliários tomada pelos órgãos societários competentes do ofertante e das decisões administrativas exigíveis, com todos os documentos que fizeram ou serviram de base para as referidas deliberações, bem como dos respectivos anúncios de convocação, se for o caso;

7. minuta do Anúncio de Início de Distribuição, o qual deve conter, no mínimo, as informações previstas no Anexo IV;

8. minuta do Anúncio de Encerramento de Distribuição, contendo, no mínimo, as informações previstas no Anexo $V$;

9. modelo do certificado de valores mobiliários ou cópia do contrato com instituição prestadora de serviço de valores mobiliários escriturais, se for o caso;

9-A. cópia da nota promissória, se for o caso;

10. Escritura de emissão de debêntures e do relatório emitido por agência classificadora de risco, se houver;

11. declaração de que o registro de companhia aberta está atualizado perante a CVM, se for o caso;

12. prova de cumprimento de todas as demais formalidades prévias em virtude de exigências legais ou regulamentares para a distribuição ou emissão dos valores mobiliários, que não decorram desta Instrução;

13. comprovante de pagamento da taxa de fiscalização, nos termos da Lei $n^{\circ} 7.940 / 89$;

14. declaração prevista no item 2.4 do Anexo III, assinada pelos representantes legais do ofertante e da instituição líder;

14-A Se for o caso, declaração da bolsa de valores ou da entidade do mercado de balcão organizado informando do deferimento do pedido de admissão à negociação do valor mobiliário, condicionado apenas à obtenção do registro na CVM.

14-B Indicação dos meios de comunicação por intermédio dos quais o aviso de que trata o art. 53 será divulgado.

14-C Declaração assinada pelo diretor de relações com investidores da companhia emissora confirmando que a companhia emissora atende a cada um dos requisitos exigidos no $\S 1^{o}$ do art. 12-E para a realização de oferta pública de distribuição vinculada a programa de distribuição $e$ atestando expressamente que:

a) a companhia emissora cumpriu, nos últimos 12 meses anteriores à data do pedido de registro automático de oferta pública de distribuição vinculada a programa de distribuição, os prazos de entrega do formulário de referência e das demonstrações financeiras anuais e trimestrais estabelecidos na norma específica;

b) as demonstrações financeiras da companhia emissora que servem de base para o pedido de registro automático de oferta pública de distribuição não estão acompanhadas de relatório da auditoria independente contendo seção separada contendo incerteza relevante relacionada com a continuidade operacional ou opinião modificada sobre as demonstrações financeiras;

c) a companhia emissora ou qualquer de suas controladas não apresentaram evento de inadimplência de dívida relevante que não esteja divulgado, de acordo com as normas contábeis aplicáveis, em nota explicativa da última demonstração financeira anual ou da última informação trimestral enviada à CVM; $e$

d) todos os documentos requeridos no art. 12-E que acompanham o pedido de registro automático, incluindo as informações incorporadas por referência no prospecto do programa, foram entregues, estão completos e foram elaborados de acordo com o conteúdo previsto nas normas específicas. 
O documento mais importante a ser apresentado na instrução do pedido de registro é o prospecto da oferta, uma vez que o mesmo deve conter informações relevantes, precisas, verdadeiras e atuais da emissão, para que os investidores possam tomar suas decisões de investimento de forma fundamentada ${ }^{37}$.

O ofertante deve entregar o prospecto não só à CVM, mas também ao investidor, pois assim, presume-se que o mesmo estará ciente dos riscos do investimento. Sobre o tema, Julio Debeux explica:

"O prospecto deve conter os dados e informações detalhadas sobre a oferta e os direitos que lhe são inerentes, sobre o ofertante, sobre a companhia emissora e sua situação patrimonial, econômica e financeira, sobre terceiros garantidores de obrigações relacionadas com os valores mobiliários e, finalmente, sobre terceiros que venham a ser destinatários dos recursos captados com a oferta" ${ }^{38}$.

A respeito do prospecto, por fim, importante apontar que a CVM exige que a seguinte mensagem conste de forma destacada na capa do documento:

"O registro da presente distribuição não implica, por parte da CVM, garantia de veracidade das informações prestadas ou em julgamento sobre a qualidade da companhia emissora, bem como sobre [valor mobiliário] a serem distribuídos(as)"39.

Com isso, entende-se que cabe ao ofertante garantir a veracidade das informações, bem como a qualidade do título ofertado. Entretanto, caso demonstrada a falta de diligência ou negligência na certificação das informações, a instituição líder também pode ser responsabilizada.

Nesse sentido, Nelson Eizirik esclarece que "a responsabilidade pelas informações prestadas é da companhia e do underwriter; já a análise

\footnotetext{
15. outras informações ou documentos exigidos pela CVM em regulação especifica".

${ }^{37}$ Artigo 38 da Instrução CVM no. 400/03: "Prospecto é o documento elaborado pelo ofertante em conjunto com a instituição líder da distribuição, obrigatório nas ofertas públicas de distribuição de que trata esta Instrução, e que contém informação completa, precisa, verdadeira, atual, clara, objetiva e necessária, em linguagem acessível, de modo que os investidores possam formar criteriosamente a sua decisão de investimento".

${ }^{38}$ DEBEUX, Julio R. Op. cit., p. 67.

${ }^{39}$ Regra expressa no Anexo IV da Instrução CVM nº. 400/2003.
} 
do mérito do empreendimento deve ser realizada pelos investidores no mercado, com base nas informações disponíveis" ${ }^{40}$.

A partir da data do protocolo, a CVM deve se manifestar acerca do pedido de registro no prazo de vinte dias úteis, o qual poderá ser interrompido uma única vez, caso a autarquia julgue necessário que a ofertante forneça novas informações para deferir o registro da emissão ${ }^{41}$.

Contudo, como já aludido anteriormente, algumas ofertas públicas não precisam atender a tais formalidades, uma vez que a CVM poderá dispensar o registro ou alguns dos requisitos previstos na Instrução CVM $n^{\circ} .400 / 2003^{42}$.

O pedido de dispensa de registro de ofertas públicas deve ser formulado pelo ofertante conjuntamente à instituição intermediária líder e, segundo o artigo $4^{\circ}, \S^{\circ}$ da Instrução CVM n ${ }^{\circ} 400 / 2003^{43}$, a CVM irá considerar os seguintes aspectos, cumulativa ou isoladamente: (i) o valor unitário dos valores mobiliários ofertados ou o valor total da oferta; (ii) o plano de distribuição dos valores mobiliários; (iii) a distribuição se realizar em mais de uma jurisdição, de forma a compatibilizar os diferentes procedimentos envolvidos, desde que assegurada, no mínimo, a igualdade de condições com os investidores locais; (iv) características da oferta de permuta (troca); (v) o público destinatário da oferta; (vi) ser dirigida exclusivamente a investidores qualificados.

\footnotetext{
${ }^{40}$ EIZIRIK, Nelson.. Aspectos Modernos do Direito Societário, 1992, p.11

${ }^{41}$ Ver artigos $8^{\circ}$ e $9^{\circ}$ da Instrução CVM n ${ }^{\circ}$. 400/2003.

${ }^{42}$ Artigo $4^{\circ}$, caput da Instrução CVM n". 400/2003: "Considerando as características da oferta pública de distribuição de valores mobiliários, a CVM poderá, a seu critério e sempre observados o interesse público, a adequada informação e a proteção ao investidor, dispensar o registro ou alguns dos requisitos, inclusive divulgações, prazos e procedimentos previstos nesta Instrução".

${ }^{43}$ Artigo $4^{\circ}, \S^{\circ}$ da Instrução CVM n'. 400/2003: "Na dispensa mencionada no caput, a CVM considerará, cumulativa ou isoladamente, as seguintes condições especiais da operação pretendida:

II - o valor unitário dos valores mobiliários ofertados ou o valor total da oferta;

III - o plano de distribuição dos valores mobiliários (art. 33, $\S 3^{\circ}$ );

IV - a distribuição se realizar em mais de uma jurisdição, de forma a compatibilizar os diferentes procedimentos envolvidos, desde que assegurada, no mínimo, a igualdade de condições com os investidores locais;

$V$ - características da oferta de permuta;

$V I$ - o público destinatário da oferta, inclusive quanto à sua localidade geográfica ou quantidade; ou

VII - ser dirigida exclusivamente a investidores qualificados".
} 
$\mathrm{O}$ artigo $5^{\circ}$ da Instrução CVM n ${ }^{\circ}$. 400/2003 ${ }^{44}$ dispõe que são automaticamente dispensadas de registro as ofertas públicas que tratam sobre: (i) alienação de ações de propriedade de pessoas jurídicas de direito público e de entidades controladas direta ou indiretamente pelo Poder Público, (ii) lote único e indivisível de valores mobiliários e, (iii) valores mobiliários de emissão de empresas de pequeno porte e de microempresas.

Assim, importante frisar que não cabe à CVM analisar o mérito do investimento, desse modo, a mesma não detém o poder de aprovar ou não uma emissão pública de valores mobiliários em função da qualidade do investimento; cabendo à autarquia apenas, por tratar-se de entidade reguladora, o deferimento ou não do registro de determinada oferta pública (ou sua dispensa), sendo este baseado em critérios formais de legalidade visando a proteção do investidor.

Feitas essas considerações acerca da atuação da CVM em ofertas públicas de valores mobiliários, passar-se-á, então, a analisar detalhadamente como a autarquia regula as ofertas públicas de condo-hotel.

\footnotetext{
${ }^{44}$ Artigo $5^{\circ}$ da Instrução CVM no. 400/2003: "Sem prejuizo de outras hipóteses que serão apreciadas especificamente pela CVM, será automaticamente dispensada de registro, sem a necessidade de formulação do pedido previsto no art. $4^{o}$, a oferta pública de distribuição:

I - de que trata a Instrução CVM no 286, de 31 de julho de 1998, que dispõe sobre alienação de ações de propriedade de pessoas jurídicas de direito público e de entidades controladas direta ou indiretamente pelo Poder Público e dispensa os registros de que tratam os arts. 19 e 21 da Lei $n^{o}$ 6.385, de 7 de dezembro de 1976, nos casos que especifica;

II - de lote único e indivisivel de valores mobiliários; $e$

III - de valores mobiliários de emissão de empresas de pequeno porte e de microempresas, assim definidas em lei".
} 


\section{Regulação da oferta-pública de condo-hotel pela CVM}

\subsection{Histórico das ofertas públicas de contrato de investimento coletivo hoteleiro}

A partir do ano de 2011, como já elucidado no Capítulo 3, o Brasil presenciou uma ascensão de empreendimentos condo-hoteleiros, os quais, até então, eram considerados apenas como investimentos imobiliários.

A CVM notou que o modelo de negócio utilizado caracterizava um contrato de investimento coletivo, nos termos do artigo $2^{\circ}$, IX da Lei $\mathrm{n}^{\circ}$. 6.385/76, como já demonstrado em capítulo anterior. Assim, toda oferta pública relativa a esse tipo de empreendimento deveria obter o competente registro perante a autarquia, como preceitua o artigo 19 da Lei de Mercado de Capitais. Contudo, em 2013, a CVM constatou que diversos ofertantes de Contrato de Investimento Coletivo (CIC) hoteleiro, por desconhecimento ou má-fé, não obedeciam a regra imposta no referido dispositivo legal.

A primeira oferta pública irregular de condo-hotel apurada pela CVM foi relacionada ao empreendimento "Village das Pedras". Isto porque a autarquia verificou que a empresa responsável pelo citado empreendimento estava oferecendo, em sua página na internet, oportunidade de investimento na modalidade de condo-hotel, sem o prévio registro na CVM.

Em vista disso, a autarquia editou a Deliberação CVM nº. 716 de 23 de outubro de 2013, a qual tinha o intuito de alertar ao público em geral e aos participantes do mercado que (i) tanto a empresa responsável pelo empreendimento quanto seu administrador não estavam habilitados para promoverem ofertas públicas de valores mobiliários; e (ii) a oferta pública em pauta não tinha sido registrada ou dispensada de registro perante a CVM. 
A referida deliberação estancou a oferta pública do empreendimento "Village das Pedras", com base no artigo 9", $\S 1^{\circ}$, I da Lei $n^{\circ} .6 .385 / 76^{45}$. Além disso, o documento tinha caráter de stop order ${ }^{46}$ e objetivava prevenir o mercado da compra de títulos sem o cumprimento das exigências preteridas em lei, como se observa abaixo:

"Determinar a todos os sócios, responsáveis, administradores e prepostos da empresa acima referida que se abstenham de ofertar ao público quaisquer valores mobiliários sem os devidos registros perante a CVM, alertando que a nãoobservância da presente determinação acarretará multa cominatória diária, no valor de $\mathrm{R} \$$ 5.000,00 (cinco mil reais), sem prejuízo da responsabilidade pelas infrações já cometidas, com a imposição da penalidade cabível, nos termos do art. 11 da Lei no 6.385 , de $1976^{\prime 47}$.

Apesar do claro posicionamento da CVM, as ofertas públicas irregulares de condo-hotel continuavam a aumentar e, por esse motivo, a autarquia publicou alerta ao mercado em 12 de dezembro de 2013, esclarecendo que os empreendimentos condo-hoteleiros ofertados publicamente deveriam ser previamente registrados perante a CVM, conforme pode-se verificar na passagem a seguir transcrita:
“A CVM vem observando a ocorrência de situações que podem configurar captação irregular de poupança popular, promovidas, em regra, por incorporadores e corretores de imóveis, através da oferta pública de oportunidades de investimento em empreendimentos imobiliários.
Nessas situações, os investidores recebem propostas de investimento por diversos meios: TV, rádio, jornais, e também por correios eletrônicos enviados por corretores de imóveis ou outros representantes de incorporadores, onde são apresentadas tais oportunidades e sua virtual lucratividade.
(...)
Por força do disposto nos art. $2^{\circ}$, inciso IX, e art. 19, ambos da Lei ${ }^{\circ} 6.385 / 76$, as ofertas de investimento que utilizarem a forma e os meios de divulgação aqui descritos devem ser previamente registradas na CVM e somente podem ser realizadas por sociedades também registradas na Autarquia.
Assim, a CVM alerta os incorporadores, corretores de imóveis e demais participantes do mercado imobiliário que somente realizem tais operações

\footnotetext{
${ }^{45} \operatorname{Art} 9^{\circ}, \S^{\circ}$, I da Lei $n^{\circ}$. 6.385/76: " $1^{\circ}$. Com o fim de prevenir ou corrigir situações anormais do mercado, a Comissão poderá: I - suspender a negociação de determinado valor mobiliário ou decretar o recesso de bolsa de valores".

${ }^{46}$ As deliberações de stop order são editadas quando a CVM verifica que determinada oferta pública de distribuição de valores mobiliários está sendo feita sem o seu competente registro ou sua dispensa perante a autarquia. Assim, tais deliberações tem o propósito de alertar ao mercado que certos agentes estão proibidos de negociar valores mobiliários publicamente, pela falta de autorização da CVM.

${ }^{47}$ Trecho retirado do inciso II da Deliberação nº . 716/2013.
} 
mediante a fiel observância da legislação em vigor, com a necessária obtenção dos prévios registros na CVM"48.

A partir do ano de 2014, os incorporadores e os operadores hoteleiros passaram a protocolar na CVM pedido de dispensa de registro para as ofertas públicas de distribuição de condo-hotel, tendo por fundamento o disposto no artigo $4^{\circ}$ da Instrução CVM n ${ }^{\circ} .400 / 2003^{49}$.

Durante os anos de 2014 e 2015 foram protocolados cerca de 60 pedidos de dispensa de registro de oferta pública de CIC hoteleiro, os quais foram apreciados individualmente pelo Colegiado da CVM ou pela Superintendência de Registro de Valores Mobiliários - SRE da autarquia.

Contudo, as dispensas de registro concedidas às ofertas públicas de condo-hotel não recebiam o mesmo tratamento das demais ofertas públicas regidas pela Instrução CVM n ${ }^{\circ}$. 400/2003. Isto porque, tendo em vista as diversas decisões da autarquia, formou-se uma espécie de "jurisprudência" para as ofertas públicas de distribuição de CIC hoteleiro.

Nesse caso, a CVM dispensava (i) a contratação de uma instituição líder (underwriter); (ii) o cumprimento dos prazos presentes na Instrução CVM nº ${ }^{\circ}$ 400/2003 relativos à duração da distribuição; e (iii) o registro da sociedade de operadora hoteleira como emissora de valores mobiliários junto à CVM.

Para que tais dispensas fossem concedidas, os ofertantes eram obrigados a atender algumas formalidades, dentre as quais destacam-se: (i) aprovação prévia de todo o material publicitário utilizado na oferta pela SRE, observando a linguagem e o conteúdo disponível; (ii) atendimento ao full disclosure, de modo a disponibilizar ao mercado informações relevantes e atuais da oferta; e (iii) restrição da oferta a investidores qualificados.

Visando a unificação, consolidação e publicização dessa "jurisprudência" de forma objetiva e clara, o Colegiado da CVM editou a

\footnotetext{
${ }^{48}$ Disponível em http://www.cvm.gov.br/noticias/arquivos/2013/20131212-1.html. Acesso em 14 mai. 2017.

${ }^{49}$ Art. $4^{\circ}$ da Instrução CVM no $.400 / 2003:$ "Considerando as características da oferta pública de distribuição de valores mobiliários, a CVM poderá, a seu critério e sempre observados o interesse público, a adequada informação e a proteção ao investidor, dispensar o registro ou alguns dos requisitos, inclusive divulgações, prazos e procedimentos previstos nesta Instrução".
} 
Deliberação CVM nº 734 em 17 de março de 2015, a qual, dentre outras determinações, delega competência à SRE para concessão de dispensa de registro de CIC hoteleiro, como será visto em tópico que segue.

\subsection{Dispensa de registro e a Deliberação CVM no. 734/2015}

A Deliberação CVM no. 734/2015 (“Deliberação 734”) foi editada com o propósito de unificar o tratamento dado às ofertas públicas de condohotel.

Nesse sentido, o documento tem o seguinte propósito:

"Delega competência à Superintendência de Registro de Valores Mobiliários para conceder dispensas em ofertas públicas de distribuição de contratos de investimento coletivo no âmbito de projetos imobiliários vinculados à participação em resultados de empreendimento hoteleiro, nas hipóteses que especifica" ${ }^{\prime 50}$.

Sobre o tema, Norma Parente explica:

"Com a nova regra, a Superintendência de Registro de Valores Mobiliários passou a examinar as operações, e não mais o Colegiado da autarquia. Uma vez realizada a análise do caso, a empresa fica autorizada a ofertar publicamente a operação de captação de recursos sem a necessidade de registro na CVM nem do ofertante, nem da própria oferta, contanto que determinadas premissas sejam observadas" ${ }^{\prime \prime}$.

Dessa forma, observadas as condições estabelecidas na Deliberação 734, os ofertantes de empreendimento condo-hoteleiro poderão encaminhar à CVM os pedidos de dispensa (i) de registro da oferta pública; (ii) de instituição intermediária e; (iii) do cumprimento dos prazos de duração da oferta presentes na Instrução CVM nº 400/2003.

Segundo a alínea "a" do inciso I da Deliberação $734^{52}$, podem ser considerados como ofertantes tanto a sociedade operadora hoteleira, como a

\footnotetext{
${ }^{50}$ Redação extraída da ementa da Deliberação CVM nº. 734/2015.

51 PARENTE, Norma Jonssen. Mercado de Capitais/Norma Jonssen Parente; coordenação Modesto Carvalhosa - São Paulo: Editora Revista dos Tribunais, 2016. - (Coleção tratado de direito empresarial; v. 6). 230 p.

${ }^{52}$ Inciso I, alínea a da Deliberação CVM n'. 734/2015: “Ofertantes: a sociedade administradora do empreendimento hoteleiro em conjunto com a sociedade incorporadora ou, na falta desta, a sociedade responsável pela oferta das partes ideais do condomínio geral”.
} 
sociedade incorporadora ou, caso esta não exista, a sociedade responsável pela oferta dos condo-hotéis.

A referida deliberação restringe as ofertas públicas de CIC em condo-hotéis a um determinado perfil de investidor, tendo em vista os riscos decorrentes do investimento e ofull disclosure.

Caso o modelo de empreendimento condo-hoteleiro for $\mathrm{o}$ de unidades imobiliárias autônomas, a oferta pública apenas poderá ser direcionada investidores que (i) possuam, pelo menos, a quantia de R\$ 1.000.000,00 (um milhão de reais) de patrimônio ou (ii) invistam, pelo menos, $\mathrm{R} \$ 300.000,00$ (trezentos mil reais) na oferta ${ }^{53}$.

Já se o modelo de exploração do condo-hotel for o de partes ideais de condomínios gerais, a oferta pública apenas será destinada a investidores qualificados $^{54}$ e que, cumulativamente, possuam, pelo menos, R\$ 1.500.000,00 (um milhão e quinhentos mil reais) de patrimônio ou invistam na oferta o valor mínimo de $\mathrm{R} \$ 1.000 .000,00$ (um milhão de reais) ${ }^{55}$.

Embora as ofertas públicas de CIC hoteleiro sejam apenas destinadas a investidores que possuam certa qualificação, isso não dispensa a observância do full disclosure, que, ainda assim, deve ser atendido.

\footnotetext{
${ }^{53}$ Regra expressa na alínea "a" do inciso III da Deliberação CVM n ${ }^{\circ}$.734/2015: "III - podem ser objeto das dispensas relacionadas no inciso II acima as ofertas de CIC envolvendo esforços de venda de:

a) unidades imobiliárias autônomas destinadas exclusivamente a investidores que possuam ao menos $R \$ 1.000 .000,00$ (um milhão de reais) de patrimônio ou invistam ao menos $R \$ 300.000,00$ (trezentos mil reais) na oferta".

${ }^{54}$ A definição de investidores qualificados está disposta no artigo $9^{\circ}$-B da Instrução CVM n ${ }^{\circ}$ 539/2014: "São considerados investidores qualificados:

I- investidores profissionais;

II - pessoas naturais ou jurídicas que possuam investimentos financeiros em valor superior a $R \$$ 1.000.000,00 (um milhão de reais) e que, adicionalmente, atestem por escrito sua condição de investidor qualificado mediante termo próprio, de acordo com o Anexo 9-B;

III - as pessoas naturais que tenham sido aprovadas em exames de qualificação técnica ou possuam certificações aprovadas pela CVM como requisitos para o registro de agentes autônomos de investimento, administradores de carteira, analistas e consultores de valores mobiliários, em relação a seus recursos próprios; $e$

IV - clubes de investimento, desde que tenham a carteira gerida por um ou mais cotistas, que sejam investidores qualificados".

${ }^{55}$ Regra expressa na alínea "b" do inciso III da Deliberação CVM no. 734/2015: "III - podem ser objeto das dispensas relacionadas no inciso II acima as ofertas de CIC envolvendo esforços de venda de: b) partes ideais de condomínios gerais destinadas exclusivamente a investidores qualificados conforme definição dada pela CVM e, ainda, que possuam ao menos $R \$ 1.500 .000,00$ (um milhão e quinhentos mil reais) de patrimônio ou invistam ao menos $R \$ 1.000 .000,00$ (um milhão de reais) na oferta".
} 
Portanto, é exigido aos ofertantes de CIC em condo-hotel a divulgação de informações verdadeiras, completas e atuais, mesmo na hipótese de dispensa de registro presente na Deliberação 734.

Assim, os ofertantes devem fornecer ao público em geral, através de sua página na internet, uma série de documentos e informações, dentre os quais destacam-se o prospecto resumido da oferta ${ }^{56}$, o estudo de viabilidade econômica do empreendimento hoteleiro ${ }^{57}$, bem como os modelos de todos os instrumentos contratuais que compõem o CIC hoteleiro ${ }^{58}$.

Todas as peças de material publicitário da oferta, para serem veiculadas, devem ser previamente aprovadas pela SRE e conter, em todas as suas páginas, a seguinte mensagem:

\author{
“A PRESENTE OFERTA FOI DISPENSADA DE REGISTRO PELA CVM. A \\ CVM NÃO GARANTE A VERACIDADE DAS INFORMAÇÕES \\ PRESTADAS PELO OFERTANTE NEM JULGA A SUA QUALIDADE OU A \\ DOS VALORES MOBILIÁRIOS OFERTADOS. ANTES DE ACEITAR A
}

\footnotetext{
${ }^{56}$ Segundo a CVM, o prospecto resumido pode ser entendido como “(...) o documento que contém todas as informações relacionadas ao empreendimento e à oferta. Nele são identificados a construtora, a incorporadora, o operador hoteleiro e demais participantes, caso existam. É no prospecto também que os investidores serão apresentados aos fatores de risco relacionados ao negócio e a um resumo das disposições contratuais que regulam as relações entre os investidores $e$ os ofertantes e entre os investidores e demais contrapartes envolvidas". Disponível em http://www.portaldoinvestidor.gov.br/portaldoinvestidor/export/sites/portaldoinvestidor/publicaca o/Boletim/BoletimCVMSENACON-8.pdf. Acesso em 29 mai. 2017.

57 De acordo com o entendimento da CVM, "o estudo de viabilidade econômica do empreendimento hoteleiro deve conter as tendências e perspectivas macroeconômicas, a análise do mercado hoteleiro por segmento e perspectivas de sua evolução, projeção de receitas, despesas e resultados para um período de pelo menos 5 (cinco) anos da operação hoteleira, cálculo da taxa interna de retorno do empreendimento para o período de 10 (dez) anos, entre outras informações relevantes para que os investidores possam avaliar economicamente a oferta. Esse estudo deve ser elaborado por profissional ou empresa independente". Disponível em http://www.portaldoinvestidor.gov.br/portaldoinvestidor/export/sites/portaldoinvestidor/publicaca o/Boletim/BoletimCVMSENACON-8.pdf. Acesso em 29 mai. 2017.

${ }^{58}$ Exigências presentes na alínea "a" do inciso IV da Deliberação CVM no. 734/2015: "IV - as dispensas relacionadas no inciso II estão condicionadas ao cumprimento cumulativo das seguintes condições:

a) os pedidos de dispensa sejam instruídos com os seguintes documentos:

1. prospecto resumido da oferta, contendo, ao menos, as informações previstas no Anexo II;

2. estudo de viabilidade econômica do empreendimento hoteleiro, elaborado por profissional ou empresa independente e que contenha, ao menos, as informações previstas no Anexo III;

3. modelo de declaração do investidor elaborado de acordo com o Anexo I;

4. modelos de todos os instrumentos contratuais que compõem o CIC;

5. declaração, assinada por no mínimo dois sócios, dois diretores estatutários, no caso de um único ofertante, ou um sócio e um diretor estatutário de cada um dos ofertantes, devidamente qualificados, de que as informações fornecidas ao público investidor durante a oferta são verdadeiras, consistentes, completas e suficientes, permitindo aos investidores uma tomada de decisão fundamentada a respeito da oferta; $e$

6. certidão de ônus reais do imóvel dentro do prazo de validade”.
} 
OFERTA LEIA COM ATENÇÃO O ESTUDO DE VIABILIDADE E O PROSPECTO RESUMIDO, EM ESPECIAL A SEÇÃO FATORES DE RISCO DISPONÍVEIS NO SITE WWW.XXXXXXX.COM.BR" ${ }^{59}$

Portanto, uma vez atendidos todos os requisitos da Deliberação 734 por parte dos ofertantes, a Superintendência de Registro de Valores Mobiliários poderá analisar e, caso todas as formalidades sejam atendidas, conceder o pedido de dispensa de registro de oferta pública de CIC hoteleiro.

\subsubsection{Direito de retratação e a Deliberação CVM no. 752/2016}

A Deliberação 734, como visto, foi editada no ano de 2015, entretanto, no ano seguinte, seu texto original foi alterado com o advento da Deliberação CVM ño 752/2016, em virtude de decisão do Colegiado tomada em 12 de abril de 2016.

A referida decisão diz respeito ao Processo CVM SEI nº. 19957.004122/2015-9960, o qual foi originado pelo pedido de dispensa de registro de oferta pública de CIC hoteleiro perante a Superintendência de Registro de Valores Mobiliários, nos termos da Deliberação 734.

Durante a análise do pedido, contudo, a SRE verificou que aproximadamente metade das unidades autônomas já tinham sido comercializadas anteriormente ao pleito. Em vista disso, a área técnica da CVM considerou tal comercialização irregular e, assim, exigiu que os ofertantes concedessem aos primeiros adquirentes a possibilidade de revogação da aceitação da oferta, isto é, o direito de retratação. Apenas após o cumprimento de tal exigência, o pedido de dispensa de registro seria atendido.

No entanto, os ofertantes discordaram da decisão da SRE e interpuseram recurso, levando a questão ao Colegiado da CVM. Os recorrentes alegaram, dentre outras questões, que o direito de retratação,

\footnotetext{
${ }^{59}$ Determinações expressas no inciso VI, alíneas "a" e "c" da Deliberação CVM no . 734/2015.

60 Disponível em http://www.cvm.gov.br/decisoes/2016/20160412 R1/20160412_D0050.html. Acesso em 14 mai. 2017.
} 
embora razoável, não seria uma condição para a concessão de registro presente na Instrução CVM nº. 400/2003, tampouco para a dispensa de registro elucidada na Deliberação 734. E, defendiam, ainda, que tal exigência nunca tinha sido imposta pelo Colegiado entre os anos de 2014 e 2015

O Colegiado da CVM, ao apreciar tal questão, decidiu, por unanimidade, pelo deferimento do recurso interposto. Porém, entendeu que o direito de retratação deveria ser observado nesses casos e, por maioria, decidiu por alterar a Deliberação 734, para que ela, a partir de então, passasse a prever o referido direito.

Abaixo transcreve-se trecho retirado do voto do Presidente da CVM, Leonardo Pereira:

“(...) entendo que a Deliberação 734 deveria ser alterada para endereçar, como condição de dispensa de registro por parte da SRE, a concessão do Direito de Retratação, pelo emissor, a todos aqueles investidores que adquiriram CICs de condo-hotel no âmbito de uma distribuição realizada sem o devido registro ou dispensa, nos termos da proposta anexa a esse voto" $"$.

Assim, tendo em vista a referida decisão, foi editada a Deliberação $\mathrm{n}^{\mathrm{o}} .752$ de 15 de abril de 2016, com o propósito de alterar os incisos I e IV da Deliberação 734.

De acordo com a nova redação, passou-se a exigir a concessão do direito de retratação aos investidores que adquiriram unidades autônomas hoteleiras sem que estas tenham sido registradas nos termos da Instrução CVM nº. 400/2003 ou dispensadas de registro de acordo com a Deliberação 734.

Dessa forma, ao inciso I da Deliberação 734 foi acrescentada a alínea "c", a seguir transcrita:

"c) direito de retratação: possibilidade de o investidor revogar a sua decisão de adquirir o CIC distribuído sem o registro de que trata a Instrução CVM no 400, de 2003, ou sem a concessão de dispensa nos termos desta Deliberação". 
Por fim, o inciso IV da referida deliberação também sofreu alterações, passando a apresentar a alínea “c”, com a seguinte redação: “c) seja concedido direito de retratação, quando aplicável, nos termos do inciso I, alínea "c", dessa Deliberação".

\subsection{Oferta pública irregular de contrato de investimento coletivo hoteleiro}

Embora a CVM regule as ofertas públicas de distribuição de CIC hoteleiro há, aproximadamente, dois anos, ainda há diversas distribuições irregulares de condo-hotel. E isto pode ser explicado pelo fato de os seus ofertantes atuarem, sobretudo, no mercado imobiliário, e não de valores mobiliários.

Contudo, essa não é uma justificativa aceitável para que os agentes desse mercado, seja por desconhecimento ou má-fé, desobedeçam as regras impostas a eles. Assim, diante de tal postura, a autarquia atua de forma mais rígida, visando o saneamento das irregularidades.

A CVM, ao se deparar com ofertas públicas irregulares de condohotel, aplica o disposto no inciso I do artigo 19 da Instrução CVM n ${ }^{\circ}$. $400 / 2003^{62}$, isto é, a autarquia edita deliberação determinando a suspensão das referidas ofertas, com o objetivo de comunicar ao mercado que elas estavam sendo veiculadas irregularmente e, imediatamente, devem ser interrompidas.

A distribuição pública irregular poderá ficar suspensa pelo prazo máximo de 30 (trinta) dias, de acordo com o $\$ 2^{\circ}$ do artigo 19 da Instrução CVM n ${ }^{\circ} .400 / 2003^{63}$. Durante esse período, a CVM orientará os ofertantes a sanarem as irregularidades presentes e seguirem o disposto na Deliberação CVM nº. 734/2015. Uma vez atendidos os seus pressupostos, a

\footnotetext{
${ }^{62}$ Art. 19 da Instrução CVM nº. 400/2003: “A CVM poderá suspender ou cancelar, a qualquer tempo, a oferta de distribuição que:

I - esteja se processando em condições diversas das constantes da presente Instrução ou do registro".

${ }^{63}$ Artigo 19, §2 da Instrução CVM nº. 400/2003: "O prazo de suspensão da oferta não poderá ser superior a 30 (trinta) dias, durante o qual a irregularidade apontada deverá ser sanada".
} 
Superintendência de Registro de Valores Mobiliários poderá, enfim, analisar o pedido de dispensa de registro daquela oferta pública.

Ademais, importante lembrar que, caso unidades do empreendimento já tiverem sido vendidas, o direito de retratação deverá ser observado, ou seja, os adquirentes das unidades hoteleiras comercializadas irregularmente poderão revogar sua compra, de acordo com o previsto no inciso IV, alínea c da Deliberação CVM no. 734/2015 64 .

No entanto, se as irregularidades não vierem a ser sanadas no prazo de 30 (trinta) dias, a oferta pública deverá cessar em caráter definitivo e o registro não será concedido, de acordo com os ditames do artigo $19, \S 3^{\circ}$ da Instrução CVM no . 400/2003 ${ }^{65}$.

A partir das pesquisas elaboradas, portanto, pode-se inferir que o maior interesse da CVM é a regulação efetiva desse mercado, de modo a proteger, sobretudo, o investidor. Além disso, é possível afirmar que a autarquia busca dar celeridade ao trâmite registrário das ofertas públicas de condo-hotel, uma vez que, como visto, elas não seguem o registro usual da Instrução CVM no . 400/2003 como a maioria das ofertas públicas, mas sim a dispensa de registro, própria da deliberação editada sobre o tema, qual seja, a Deliberação CVM nº.734/2015.

Contudo, o colegiado da CVM vem estudando a possibilidade de tentar modificar essa prática, de maneira a passar a conceder o registro das ofertas públicas de condo-hotel, e não mais a sua dispensa, como será abordado em tópico que segue.

\subsection{Audiência pública acerca de instrução sobre a oferta pública de distribuição de $\mathrm{CIC}$ hoteleiro}

\footnotetext{
${ }^{64}$ Inciso IV, alínea c da Deliberação CVM n ${ }^{\circ} .734 / 2015$ : "seja concedido direito de retratação, quando aplicável, nos termos do inciso I, alínea "c", dessa Deliberação".

${ }^{65}$ Artigo $19, \S^{\circ}$ da Instrução CVM n ${ }^{\circ}$. 400/2003: "Findo o prazo referido no $\$ 2^{\circ}$ sem que tenham sido sanados os vícios que determinaram a suspensão, a CVM deverá ordenar a retirada da oferta e cancelar o respectivo registro".
} 
Após alguns anos lidando com as ofertas públicas de CIC hoteleiro, a CVM adquiriu experiência no assunto e detectou certas questões que mereciam atenção e deveriam ser discutidas com os agentes do mercado, visando uma melhor regulamentação.

Em vista disso, em 10 de novembro de 2016, a autarquia submeteu à audiência pública minuta de instrução que trata sobre a oferta pública de distribuição de CIC hoteleiro.

A partir de tal minuta, os agentes do mercado tiveram um período para analisar o documento e enviar à CVM sugestões de melhorias que iriam beneficiar a regulação do mercado condo-hoteleiro como um todo.

A nova instrução propõe regular apenas as ofertas públicas de CIC hoteleiro de unidades autônomas, ao passo que as ofertas públicas envolvendo a comercialização de frações ideais de condomínios voluntários ficariam sujeitas aos mandamentos da Instrução CVM nº. 400/2003.

Essa dissociação pode ser explicada da seguinte forma, segundo a CVM:

"Essa escolha se justifica na medida em que a Minuta estabelece disciplina específica que leva em consideração peculiaridades do regime jurídico da incorporação imobiliária e do condomínio edilício, notadamente a proteção de que goza o adquirente da unidade autônoma, nos termos da Lei $n^{\circ} 4.591$, de 16 de dezembro de $1964 "$ "66.

Com a nova instrução, portanto, não mais seriam aplicadas a Instrução CVM nº. 400/2003, tampouco a Deliberação CVM nº. 734/2015 às ofertas públicas de distribuição de CIC hoteleiro de unidades autônomas, uma vez que a minuta visa estabelecer um marco regulatório.

Assim, de acordo com o Edital de Audiência Pública SDM nº. 08/2016:

"A CVM pretende com a Minuta alcançar os seguintes objetivos: a) contribuir para o desenvolvimento sustentável de setor hoteleiro no Brasil, ampliando e melhorando o acesso de incorporadores e operadores hoteleiros ao mercado de

${ }^{66}$ Trecho retirado do item "1. Introdução" do Edital de Audiência Pública SDM nº. 08/2016, disponível

http://www.cvm.gov.br/export/sites/cvm/audiencias_publicas/ap_sdm/anexos/2016/sdm0816edital .pdf. Acesso em 14 mai. 2017. 
valores mobiliários para o financiamento de suas atividades; b) assegurar a adequada proteção dos investidores em condohotel, tendo em conta a complexidade e os riscos inerentes ao CIC hoteleiro; e c) promover a segurança jurídica por meio da clara definição dos deveres e responsabilidades de cada um dos participantes da oferta pública"67.

A minuta em análise busca aperfeiçoar a regulação das ofertas públicas de CIC hoteleiro, não esquecendo do regime disposto na Deliberação CVM ño. 734/2015. Com isso, importante é a análise das principais inovações do documento, como será feito a seguir.

Primeiramente, a minuta preconiza que as ofertas públicas de CIC hoteleiro passem a ser registradas na CVM, e não mais dispensadas de registro pela SRE. Contudo, excepcionalmente, poderão ser concedidas dispensas automáticas de registro nas seguintes hipóteses: (i) as situações nas quais remanesce ao final da oferta pública, já analisada pela CVM, um estoque de unidades autônomas (equivalentes a até $10 \%$ da totalidade do empreendimento) não distribuídas em mãos do incorporador ou de outro participante da incorporação imobiliária, como o dono do terreno, o construtor ou o fornecedor de materiais utilizados na construção ${ }^{68}$; (ii) a distribuição pública que compreenda, exclusivamente, unidades autônomas que tenham sido objeto de retratação, distrato ou rescisão contratual e integrem empreendimento hoteleiro que já tenha sido objeto de distribuição pública registrada ou dispensada de registro pela $\mathrm{CVM}^{69}$; (iii) as situações em que o investidor procura desfazer-se do seu investimento, cedendo a terceiro as suas unidades autônomas (limitado a cinco unidades) e a sua posição no CIC hoteleiro $^{70}$.

\footnotetext{
${ }^{67}$ Redação presente no item "1. Introdução" do Edital de Audiência Pública SDM nº . 08/2016.

${ }^{68}$ Art. 29, inciso I da Minuta de Instrução sobre a oferta pública de distribuição de CIC hoteleiro:

"Encontra-se automaticamente dispensada de registro, sem a necessidade do pedido de que trata $o$ art. $6^{\circ}$, a oferta pública de distribuição de CIC hoteleiro que:

I - compreenda até $10 \%$ das unidades autônomas de empreendimento hoteleiro que já tenha sido objeto de distribuição pública registrada ou dispensada de registro pela CVM".

${ }^{69}$ Art. 29, inciso II da Minuta de Instrução sobre a oferta pública de distribuição de CIC hoteleiro: "Encontra-se automaticamente dispensada de registro, sem a necessidade do pedido de que trata o art. $6^{\circ}$, a oferta pública de distribuição de CIC hoteleiro que:

II - compreenda, exclusivamente, unidades autônomas que tenham sido objeto de Direito de Retratação, distrato ou rescisão contratual e integrem empreendimento hoteleiro que já tenha sido objeto de distribuição pública registrada ou dispensada de registro pela CVM".

${ }^{70}$ Art. 30 da Minuta de Instrução sobre a oferta pública de distribuição de CIC hoteleiro:

"Também se encontra automaticamente dispensada de registro a oferta pública de distribuição de
} 
Ademais, o documento visa estabelecer prazos mais precisos quanto ao início e fim da distribuição pública. Segundo o artigo 16 da Minuta de Instrução sobre a oferta pública de distribuição de CIC hoteleiro: "O registro de distribuição do CIC hoteleiro caducará se o Anúncio de Início de Distribuição não for divulgado em 180 (cento e oitenta) dias após a sua obtenção".

Já no que diz respeito ao encerramento da distribuição, o documento deixa a questão aberta à sugestões dos agentes do mercado, para que os mesmos apresentem o prazo mais adequado ao cumprimento de todas as formalidades.

Outro ponto inovador está relacionado ao destinatário da oferta. A princípio, se manteriam alguns pressupostos dispostos na Deliberação CVM $n^{\circ}$. 734/2015, são eles: (i) os investidores qualificados; e (ii) os investidores que possuem, pelo menos, $\mathrm{R} \$ 1.000 .000,00$ (um milhão de reais) de patrimônio $^{71}$.

A minuta sugere a criação de novo critério alternativo, de modo a autorizar como destinatários das ofertas de CIC hoteleiros aqueles que já possuem, ao menos, um investimento em condo-hotel, cujo empreendimento esteja funcionando há mais de um ano ${ }^{72}$.

Contudo, é proposta a exclusão do atual critério presente na Deliberação CVM no. 734/2015 que determina o investimento mínimo de $\mathrm{R} \$ 300.000,00$ (trezentos mil reais) no CIC hoteleiro, uma vez que, segundo o documento, tal critério "pode gerar distorções indesejáveis entre

CIC hoteleiro que corresponda à revenda de até 5 (cinco) unidades autônomas de empreendimento hoteleiro".

${ }^{71}$ Art. $5^{\circ}$, inciso II da Minuta de Instrução sobre a oferta pública de distribuição de CIC hoteleiro: "As ofertas públicas de distribuição de CIC hoteleiro, realizadas nos termos desta Instrução, devem ser destinadas exclusivamente:

I- aos investidores considerados qualificados, nos termos da regulamentação específica da CVM; II - às pessoas naturais ou jurídicas que possuam, ao menos, $R \$ 1.000 .000$ (um milhão de reais) de patrimônio e que, adicionalmente, subscrevam o termo previsto no Anexo 5 ".

${ }^{72}$ Art. $5^{\circ}$, inciso III da Minuta de Instrução sobre a oferta pública de distribuição de CIC hoteleiro: "As ofertas públicas de distribuição de CIC hoteleiro, realizadas nos termos desta Instrução, devem ser destinadas exclusivamente:

III - às pessoas naturais ou jurídicas que possuam, ao menos, um investimento em CIC cujo empreendimento hoteleiro esteja em operação por prazo superior a um ano e que, adicionalmente, subscrevam o termo previsto no Anexo 5 ". 
empreendimentos hoteleiros, tendo em vista a variação significativa do preço das unidades autônomas nas diferentes regiões do país"73.

Além disso, a minuta prevê alterações, ainda, concernentes à atuação dos corretores de imóveis. Segundo o documento, as incorporadoras hoteleiras passarão a ser responsáveis pela fiscalização da atividade dos corretores, visando o cumprimento das normas em vigência ${ }^{74}$.

Outra novidade está relacionada ao material publicitário da oferta. A partir de então não será mais necessária a aprovação prévia de tal material perante a SRE, uma vez que é proposta uma fiscalização a posteriori ${ }^{75}$. De acordo com a minuta:

“A SRE adotará nessa direção rotinas de supervisão e, quando identificar irregularidades em determinado material publicitário, adotará as medidas corretivas e sancionadoras apropriadas, as quais incluem, notadamente, a possibilidade de suspensão da oferta em curso"76.

Por fim, a última alteração relevante diz respeito à dispensa de cumprimento das obrigações de informação pela operadora hoteleira. A minuta propõe que após o terceiro ano de funcionamento do empreendimento hoteleiro, os condôminos, reunidos em assembleia, possam dispensar a operadora hoteleira da divulgação de informações financeiras anuais e trimestrais ${ }^{77}$.

\footnotetext{
${ }^{73}$ Trecho extraído do item "3.3. Público destinatário da oferta" do Edital de Audiência Pública SDM n ${ }^{\circ} .08 / 2016$.

${ }^{74}$ Art. 16 da Minuta de Instrução sobre a oferta pública de distribuição de CIC hoteleiro: " $A$ sociedade incorporadora deve fiscalizar a atividade dos corretores de imóveis, adotando práticas e procedimentos destinados a assegurar o cumprimento do disposto nesta Instrução".

${ }^{75}$ Art. 23 da Minuta de Instrução sobre a oferta pública de distribuição de CIC hoteleiro: " $A$ utilização de qualquer texto publicitário para oferta, anúncio ou promoção da distribuição, por qualquer forma ou meio veiculados, não depende de prévia aprovação da SRE, ficando os ofertantes responsáveis pela conformidade do material com as disposições desta Seção.

$\S 1^{\circ}$ Se assim quiserem, os ofertantes podem submeter, uma única vez, o material publicitário que pretendem utilizar na oferta à aprovação da SRE, concomitantemente ao pedido de registro da oferta.

$\S 2^{\circ}$ Ainda que tenha autorizado a utilização do material publicitário, a SRE pode, a qualquer momento, por decisão motivada, requerer retificações, alterações ou mesmo a cessação da publicidade".

${ }^{76}$ Redação retirada do item "3.6. Material publicitário" do Edital de Audiência Pública SDM nº. $08 / 2016$.

${ }^{77}$ Art. 34 da Minuta de Instrução sobre a oferta pública de distribuição de CIC hoteleiro: "A partir do terceiro ano após o início do funcionamento do empreendimento hoteleiro, os condôminos, reunidos em assembleia, podem dispensar a sociedade operadora do cumprimento de uma ou de ambas as obrigações previstas no art. 33".
} 
Para tal, "a convenção do condomínio deverá conter dispositivo prevendo que tal deliberação deve ser aprovada por maioria simples, desde que corresponda a 20\% (vinte por cento) das frações ideais"78.

Assim, tendo em vista que o prazo para manifestação dos agentes do mercado já expirou, a CVM vem analisando a melhor forma de editar uma instrução que atenda às necessidades do mercado condo-hoteleiro. Contudo,

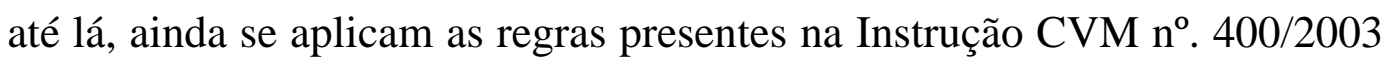
e na Deliberação CVM nº. 734/2015.

Portanto, o tema em análise ainda sofrerá diversas mudanças cujos efeitos serão observados num futuro próximo. O resultado da audiência pública será uma contribuição para a edição da instrução normativa levando em conta a opinião do mercado. O seu teor, assim que disponível, como as demais audiências públicas, servirá para melhor compreensão dos objetivos e finalidade da norma a partir de sua entrada em vigor.

\footnotetext{
${ }^{78}$ Trecho extraído do item "3.7. Dispensa de cumprimento das obrigações de informação pela sociedade operadora do empreendimento hoteleiro" do Edital de Audiência Pública SDM nº. $08 / 2016$.
} 


\section{Conclusão}

O presente trabalho teve por objetivo a análise do tratamento empregado pela CVM às ofertas públicas de CIC hoteleiro, uma vez que, por se tratar de um tema recente no mercado de valores mobiliários, merece ser refletido cautelosamente.

O estudo das ofertas públicas de condo-hotel, reguladas pela Deliberação CVM nº.734/2015, vem se tornando, com os avanços do mercado de capitais, cada vez mais relevante, não só para os seus agentes, mas, sobretudo, para a Comissão de Valores Mobiliários, dado que a autarquia é o órgão estatal responsável pela regulação de tal mercado.

A partir dos estudos realizados, é notório que o condo-hotel, embora por muito tempo tenha sido visto apenas como um bem imobiliário, possui peculiaridades próprias de valores mobiliários e, assim pode ser caracterizado.

Isto se deve às suas principais características, são elas: os ofertantes são uma incorporadora e/ou uma operadora hoteleira; há um contrato de Sociedade em Conta de Participação (SCP), cujas partes devem ser uma incorporadora e/ou adquirente como sócios participantes e a operadora hoteleira como sócia ostensiva; o sistema de exploração do empreendimento obriga a adesão dos adquirentes ao "pool de locação", através dos contratos de SCP e de compra e venda, em que a operadora hoteleira estará incumbida de gerenciar e explorar as unidades autônomas, através do contrato de locação; a utilização do adquirente não dá direito de posse direta da unidade hoteleira, podendo apenas utilizá-la como hóspede, desde que pague uma diária.

Sendo assim, esse panorama demandou que as atribuições fiscalizadora e reguladora da CVM fossem realizadas de forma eficiente buscando mapear as ofertas públicas de condo-hotel e dar a elas o seu devido tratamento. 
Como visto, a regulação das ofertas públicas de CIC hoteleiro passou, em período relativamente curto, por diversas modificações, as quais foram de liberdade total, passando por uma regulação permissiva, até uma regulação própria e mais complexa, devido, sobretudo, à necessidade de proteção do investidor.

Essas mudanças foram necessárias para que a tratativa de tais ofertas estivessem em consonância com um setor da economia que presenciou um desenvolvimento vertiginoso, em função dos eventos esportivos sediados pelo Brasil, e que estava carente de regulamentação.

Quando os condo-hotéis surgiram no país, em 2011, os agentes desse mercado passaram a ofertá-los irregularmente, não por má-fé, mas, sobretudo, por desconhecerem o seu caráter de investimento financeiro e, por conseguinte, que deveriam acatar às normas impostas pela CVM

A opção da autarquia por passar a registrar as ofertas públicas de CIC hoteleiro veio estabelecer um marco regulatório. A partir de agora espera-se, portanto, que a atuação da CVM torne-se mais efetiva e notória no mercado de condo-hotel.

Como esse é um tema muito atual, o mesmo ainda é suscetível a diversas mudanças, as quais, como visto, estão a ponto de ocorrer. Assim, espero que o presente trabalho tenha respondido às principais questões acerca do assunto, ou pelo menos, tenha servido para a reflexão sobre sua importância e impulsionado o seu estudo. 


\section{Referências Bibliográficas}

1. CHEDIAK, Julian Fonseca Peña. "A reforma do mercado de valores mobiliários".In: LOBO, Jorge; KANDIR, Antonio (Coords.). Reforma da Lei das Sociedades Anônimas: inovações e questões controvertidas da Lei n. 10.303, de 31.10.2001. 2. ed. Rio de Janeiro: Forense, 2002. p. 525544. Forense, 2002.

2. COMISSÃO DE VALORES MOBILIÁRIOS. Oferta pública $\begin{array}{llll}\text { primária } & e & \text { secundária. } & \text { Disponível }\end{array}$ http://www.portaldoinvestidor.gov.br/menu/Menu_Investidor/ofertas/oferta s_publicas.html). Acesso em 23 abr. 2017.

3. COMISSÃO DE VALORES MOBILIÁRIOS. Processo CVM N. RJ2007/11.593, Rel. Diretor Marcos Barbosa Pinto, Rio de Janeiro, 22 jan. 2008.

4. COMISSÃO DE VALORES MOBILIÁRIOS. Processo CVM SEI n. ${ }^{\circ} 19957.006485 / 2016-40$.

5. COMISSÃO DE VALORES MOBILIÁRIOS e Senacon/MJ. $8^{a}$ edição do Boletim de Proteção do Consumidor/Investidor. Disponível em http://www.portaldoinvestidor.gov.br/portaldoinvestidor/export/sites/portal doinvestidor/publicacao/Boletim/BoletimCVMSENACON-8.pdf. Acesso em 15 abr. 2017.

6. COMISSÃO DE VALORES MOBILIÁRIOS. O mercado de valores mobiliários brasileiro. $3^{\mathrm{a}}$. ed. Rio de Janeiro: Comissão de Valores Mobiliários, 2014.

7. DEBEUX, Julio R. A Comissão de Valores Mobiliários e os principais instrumentos regulatórios do mercado de capitais brasileiro. Porto Alegre. Sergio Antonio Fabris Ed., 2006.

8. Deliberação CVM no 716/2013. Disponível em http://www.cvm.gov.br/export/sites/cvm/legislacao/deli/anexos/0700/deli71 6.pdf. Acesso em 14 mai. 2017. 
9. Deliberação CVM $\quad \mathrm{n}^{\mathrm{o}}$. 734/2015. Disponível em http://www.cvm.gov.br/export/sites/cvm/legislacao/deli/anexos/0700/deli73 4consolid.pdf. Acesso em 14 mai. 2017.

10. Deliberação CVM $\mathrm{n}^{\circ}$. 752/2016. Disponível em http://www.cvm.gov.br/export/sites/cvm/legislacao/deli/anexos/0700/deli75 2.pdf. Acesso em 14 mai. 2017.

11. EIZIRIK, Nelson. Aspectos Modernos do Direito Societário, Renovar, Rio de Janeiro, 1992.

12. EIZIRIK, Nelson et al. Mercado de Capitais - Regime Jurídico. $3^{\mathrm{a}}$ ed. Revista e ampliada - Rio de Janeiro: Renovar, 2011.

13. HAZEN, Thomas Lee, The Law of Securities Regulation. $5^{\mathrm{a}}$ edição, Thomson/West, Hornbook Series, 2005.

14. Instrução CVM $\mathrm{n}^{\circ}$. 400/2003. Disponível em http://www.cvm.gov.br/export/sites/cvm/legislacao/inst/anexos/400/inst400 consolid.pdf. Acesso em 23 abr. 2017.

15. Instrução CVM $n^{\circ}$. 539/2014. Disponível em http://www.cvm.gov.br/export/sites/cvm/legislacao/inst/anexos/500/inst539 consolid.pdf. Acesso em 29 mai. 2017.

16. LEÃES, Luiz Gastão Paes de Barros. "O conceito de "security" no direito norteamericano e o conceito análogo no direito brasileiro". Revista de Direito Mercantil, Industrial, Econômico e Financeiro, v.13, nova série, n. 14, p. 41-60, 1974.

17. Lei $\quad \mathrm{n}^{\circ}$. $4.591 / 64 . \quad$ Disponível em http://www.planalto.gov.br/ccivil 03/leis/L4591.htm. Acesso em 15 abr. 2017.

18. Lei $\quad n^{\circ}$. $4.728 / 65$ Disponível em http://www.planalto.gov.br/ccivil_03/leis/L4728.htm. Acesso em 02 mar. 2017.

19. Lei $\mathrm{n}^{\circ}$. $6.385 / 76$. Disponível em http://www.planalto.gov.br/ccivil_03/leis/L6385.htm. Acesso em 02 mar. 2017. 
20. Lei $\mathrm{n}^{\mathrm{o}}$. $6.404 / 76$. Disponível em http://www.planalto.gov.br/ccivil_03/leis/L6404consol.htm. Acesso em 23 abr. 2017.

21. Lei $\mathrm{n}^{\mathbf{0}}$ 10.406/02. Disponível em http://www.planalto.gov.br/ccivil_03/leis/L6404consol.htm. Acesso em 15 abr. 2017.

22. Lei $\mathrm{n}^{\mathbf{o}}$ 11.771/08. Disponível em http://www.planalto.gov.br/ccivil_03/_ato2007-2010/2008/lei/111771.htm. Acesso em 15 abr. 2017.

23. MATTOS FILHO, Ary Oswaldo. Direito dos valores mobiliários. Volume 1: Tomo 1. Editora FGV, 2015.

24. NETO, José Ernesto Marino. Condo-hotel hoje: responsabilidades, riscos e consequências - Artigo de José Ernesto Marino Neto. Disponível em http://www.revistahoteis.com.br/condo-hotel-hoje-responsabilidadesriscos-e-consequencias-artigo-de-jose-ernesto-marino-neto/ Acesso em 12 abr. 2017.

25. PARENTE, Norma Jonssen. Mercado de Capitais / Norma Jonssen Parente; coordenação Modesto Carvalhosa - São Paulo: Editora Revista dos Tribunais, 2016. - (Coleção tratado de direito empresarial; v. 6).

26. SILVA, Paulo Ferreira Dias da. CVM e a Regulação dos CondoHoteis. FOHB. 05 mai. 2015.

27. Supreme Court of the United States, 1946, 328 U.S. 293. Disponível em https://supreme.justia.com/cases/federal/us/328/293/case.html Acesso em 29 mai. 2017.

28. http://www.cvm.gov.br/decisoes/2016/20160412_R1/20160412_D0 050.html Acesso em 14 mai. 2017.

29. http://www.cvm.gov.br/export/sites/cvm/audiencias_publicas/ap_sd m/anexos/2016/sdm0816edital.pdf Acesso em 14 mai. 2017.

30. http://www.cvm.gov.br/export/sites/cvm/decisoes/anexos/0004/5730 -0.pdf.. Acesso em 02 mar. 2017. 
31. http://www.cvm.gov.br/export/sites/cvm/decisoes/anexos/2016/2016 0412/0050 Voto_PTE.pdf Acesso em 14 mai. 2017.

32. http://www.cvm.gov.br/export/sites/cvm/decisoes/anexos/2017/2017 0221/0583.pdf. Acesso em 16 abr. 2017.

33. http://www.cvm.gov.br/noticias/arquivos/2013/20131212-1.html Acesso em 14 mai. 2017

34. https://www.ftc.gov/ Acesso em 04 jun. 2017.

35. https://www.sec.gov/ Acesso em 29 mai. 2017.

36. https://www.sec.gov/about/laws/sa33.pdf Acesso em 29 mai. 2017.

37. https://www.sec.gov/about/laws/sea34.pdf Acesso em 29 mai. 2017. 